\title{
Estrogenic and cytotoxic potentials of compounds isolated from Millettia macrophylla Benth (Fabaceae): towards a better understanding of its underlying mechanisms
}

Stéphane Zingue ${ }^{1,2,34^{*}}$, Job Tchoumtchoua ${ }^{2,3}$, Dieudonnée Mireille Ntsa², Louis Pergaud Sandjo ${ }^{4}$, Julia Cisilotto ${ }^{4}$, Chantal Beatrice Magne Nde ${ }^{5}$, Evelyn Winter ${ }^{4}$, Charline Florence Awounfack ${ }^{2}$, Derek Tantoh Ndinteh ${ }^{6}$, Colin Clyne ${ }^{5}$, Dieudonné Njamen ${ }^{2,6}$, Maria Halabalaki ${ }^{3}$ and Tânia Beatriz Creczynski-Pasa ${ }^{4^{*}}$

\begin{abstract}
Background: Millettia macrophylla was previously reported to have estrogenic effects and to prevent postmenopausal osteoporosis in Wistar rats. So, the study deals with the identification of its secondary metabolites and the evaluation of their estrogenicity and cytotoxicity toward tumoural cells. Thus, 13 known compounds were obtained from successive chromatographic columns and identified by NMR data compared to those previously reported.
\end{abstract}

Methods: In vitro estrogenicity of the isolates and the phenolic fraction (PF) of M. macrophylla were performed by E-screen and reporter gene assays, while their cytotoxicity was evaluated by Alamar Blue (resazurin) assay. A 3-days uterotrophic assay and the ability of PF to alleviate hot flushes in ovariectomized adult rats were tested in vivo.

Results: Seven of the 13 secondary metabolites turned to be estrogenic. Only two exhibited cytotoxic effects on MCF-7 and MDA-MB-231 with CC 50 values of $110 \mu \mathrm{M}$ and $160 \mu \mathrm{M}$, respectively. PF induced a significant $(p<0.01)$ MCF-7 cells proliferation and transactivated both ERa and ERß in the reported gene assay at $10^{-2} \mu \mathrm{g} / \mathrm{mL}$. In vivo, PF acted more efficiently than the methanol crude extract, resulting to a significant $(p<0.01)$ increase in the uterine wet weight, uterine protein level, uterine and vaginal epithelial height at the dose of $10 \mathrm{mg} / \mathrm{kg} \mathrm{BW}$. In addition, PF reduced the average duration and frequency of hot flushes induced in rat.

Conclusion: These aforementioned results indicate that PF is a good candidate for the preparation of an improved traditional medicine able to alleviate some menopausal complaints such as vaginal dryness and hot flushes.

Keywords: Millettia macrophylla, Phytoestrogens, Estrogen-dependent cancer, Cytotoxicity, E-screen assay, Uterotrophic assay

\footnotetext{
* Correspondence: stephanezingue@gmail.com; tania.pasa@ufsc.br

'Laboratory of Physiology and Natural Products Research, Department of Live and Earth Sciences, Higher Teachers' Training College, University of Maroua, P.O. Box 55, Maroua, Cameroon

${ }^{4}$ Department of Pharmaceutical Sciences, Health Sciences Centre, Federal University of Santa Catarina, CEP 88040-900 Florianópolis, Santa Catarina, Brazil

Full list of author information is available at the end of the article
} 


\section{Background}

Cancer is a leading cause of death and a major public concern worldwide. More than 1.1 million people are diagnosed every year with cancer among them 410,000 deaths [1]. In developing countries, gynecological and mammary cancers (breast, uterus, and ovarian) account for $19 \%$ of cancers worldwide and are among the leading causes of morbidity and mortality in these countries [2]. Chemotherapy and surgery remain the major treatments of this ailment although side effects and the treatment expense represent two major difficulties for affected patients, especially those from Sub-Saharan Africans. These two factors make approximately $80 \%$ of the population rely and use medicinal plants for their primary healthcare problems or as an alternative solution to cure diseases [3]. Nowadays, there is a recrudescence of interest for the natural alternative such as medicinal plants and dietary means. Even in developing countries, this phenomenon is observed because of their efficacy and toxicity tolerance $[4,5]$. So, medicinal plants are increasingly screened for seeking anticancer hits and numerous phytoconstituents have already been reported to be cytotoxic toward breast tumour cells and to prevent or abrogate tumours induced in rats [6-9]. Phytoestrogens are plant metabolites with the chemical structure shaped as that of $17 \beta$-estradiol and mimic estrogenic actions in mammals [10]. Natural estrogenic compounds include coumestans, isoflavonoids and flavonoids $[11,12]$. Since they are endowed with both estrogenic and antiestrogenic properties, these natural selective estrogen receptors modulators are now promoted as a preventive alternative against estrogendependent cancers such as breast, ovarian, uterine and prostate cancers [13].

As part of our continuous search of new phytoestrogens, we focused the study on Millettia macrophylla (Fabaceae), a plant growing in sub-Saharan Africa. It is used for the treatment of respiratory difficulties, constipation, colds and headaches, jaundice as well as some physiological disorders related to menopause [14, 15]. There are also evidences suggesting that plants belonging to the genus Millettia can boost the immune system, and even fight some forms of cancer $[16,17]$. Our previous work showed that M. macrophylla dichloromethane (DCM) and methanol (MeOH) extracts have estrogenlike effects on estrogen target organs of ovariectomized Wistar rats and prevent postmenopausal osteoporosis $[18,19]$. In addition the estrogen-like effects of these extracts were inhibited in vitro and in vivo by the pure ER antagonist ICI 182, 780 (Fulvestrant), indicating that their effects were primarily mediated through ERs [20]. These findings suggest the presence of estrogenic/antiestrogenic compounds in $M$. macrophylla helpful for the treatment of estrogen-dependent cancers, since two thirds of newly diagnosed invasive breast tumors are estrogen-dependent [21]. The present study therefore aimed to identify and isolate the major compounds present in $M$. macrophylla and to assess their estrogenic and cytotoxic effects.

\section{Methods \\ Plant material and extraction}

Stem barks of Millettia macrophylla were collected in Kumba (South-west Region of Cameroon) in January 2010 and identified at the Cameroon National Herbarium (CNH) (Voucher specimen $\mathrm{N}^{\circ} 49654 / \mathrm{HNC}$ ) by the botanist M. Victor Nana. The well-dried and pulverized stem bark of this plant $(2,500 \mathrm{~g})$ was extracted successively with $\mathrm{DCM}$ and $\mathrm{MeOH}(10 \mathrm{~L}$ of each solvent $\times 3$; $72 \mathrm{~h}$ per extraction). Following concentration under reduce pressure, $25 \mathrm{~g}$ (1\%) of dichloromethane and $53.4 \mathrm{~g}$ $(2.14 \%)$ of methanol crude extracts were obtained.

Isolation of compounds from M. macrophylla DCM extract Eight grams of DCM extract was chromatographed using a normal phase Medium Pressure Liquid Chromatography (MPLC, BÜCHI Labortechnik AG) conditioned in a column with metal sheath glass $(36 \times 460 \mathrm{~mm})$, adapted to the pressure of work (15 bar). A glass precolumn was used to reduce the load imposed on the walls of the column. The stationary phase consisted of silica gel $60 \mathrm{H}$ (granulometry 20-40 $\mu \mathrm{m}$ ). The mobile phase consisted of a binary mixture of solvent of hexane-dichloromethane-ethylacetate-methanol of increasing polarity by step gradient using the pump Büchi C-605, to yield 875 fractions collected and combined on the basis of TLC and HPLC analysis into 40 collective fractions (F1 - F40). The fractions F5 (50-60; $158.6 \mathrm{mg})$, F10 (123-156; $913.2 \mathrm{mg})$, F14 (299-353, $328.2 \mathrm{mg})$ and F18 (439-495, $108 \mathrm{mg}$ ) were pure and correspond to compounds $1,2,3$, and 4 , respectively.

A qualitative evaluation of the fractions by TLC and HPLC-PDA (using a gradient method with $\mathrm{H}_{2} \mathrm{O}+2 \%$ acetic acid and $\mathrm{CH}_{3} \mathrm{CN}+2 \%$ acetic acid) was performed in order to select fractions rich in flavonoids and isoflavonoids. Thus, fractions F15 (354-405; $212.4 \mathrm{mg}$ ) were subjected to a preparative TLC developed in c-hex/EtOAc: 70/ 30 (v/v) to give 2. From the fraction F25 (838-850; $44 \mathrm{mg})$, compound $5(2.4 \mathrm{mg})$ was isolated using preparative TLC developed with c-hex/EtOAc: 70/30 (v/v). The F33 (864) and F34 (865) were merged (100 mg) and filtered through a Sephadex LH-20 column (bead size: $25-100 \mu \mathrm{m})$. From this fraction, 74 subfractions were obtained. From subfractions 32-41 (24.7 mg), compound 6 (4.1 mg) was obtained after purification on preparative TLC, developed in c-hex/ EtOAc: 70/30. Subfractions 42-54 (25 mg) was subjected to preparative TLC using c-hex/EtOAc: 70/30 (v/v) affording to compounds $6(5.7 \mathrm{mg})$ and $7(3.3 \mathrm{mg})$. 


\section{Isolation of compounds from M. macrophylla phenolic fraction (PF)}

In order to maximize phenolic compounds isolation, a $M$. macrophylla phenolic fraction (PF) was prepared using resin enrichment technology. To achieve this goal the Amberlite XAD-7PH resin (Rhom and Hass, France) was used. The resin was conditioned with excess of distilled water and activated in ethanol -EtOH $\left(96.30^{\circ}\right)$ overnight. $\mathrm{EtOH}$ was removed by rinsing the activated resin with distilled water. Then, $52 \mathrm{~g}$ of $M$. macrophylla $\mathrm{MeOH}$ crude extract were diluted in distilled water and sonicated (Elmasonic $\mathrm{S} 100 \mathrm{H}$ at $40{ }^{\circ} \mathrm{C}$ for $1 \mathrm{~h}$ ). Further, the obtained solution was subjected to a separating funnel $(2,000 \mathrm{~L})$ containing $400 \mathrm{mg}$ of Amberlite XAD-7PH resin, rinsed many times with distilled water and the water-soluble fraction was collected. The phenolics adsorbed by the resin were eluted using $\mathrm{EtOH}$ and the obtained phenolic fraction was concentrate in a rotavapor to afford $7.16 \mathrm{~g}$ of phenolic fraction (PF).

Six grams of phenolic fraction was chromatographed using a Medium Pressure Liquid Chromatography (MPLC) as described above with the slight difference that the column size was $36 \times 460 \mathrm{~mm}$ and the applied pressure was 20 bar. The stationary phase consisted of silica gel RP-18 (granulometry 40-63 $\mu \mathrm{m}$ ). The mobile phase consisted of a binary mixture of solvent of water-ethanol of increasing polarity by step gradient using the pump Büchi C-605, to yield 693 fractions collected and combined on the basis of TLC and HPLC analysis into 26 collective fractions. Fractions from F9 to F13 (226-380) were merge (240 mg) and subjected to a Sephadex LH-20 gel filtration. Compounds $8(2 \mathrm{mg})$ and $9(1 \mathrm{mg})$ were isolated using preparative TLC developed with $\mathrm{DCM} / \mathrm{MeOH}(98 / 02: \mathrm{v} / \mathrm{v})$ of subfractions 77-87 (14.1 mg). Subfractions from 88 to 98 (13.1 mg) were subjected to preparative TLC developed with DCM/ $\mathrm{MeOH}(95 / 05: \mathrm{v} / \mathrm{v})$ to afford compounds $9(1 \mathrm{mg})$ and 10 (0.9 mg). Compound 11 (1.7 mg) was obtained after purification with preparative TLC developed with $\mathrm{DCM} / \mathrm{MeOH}$ (93/07: v/v) of subfractions 104-116 (12.5 mg). From the initial fractionation, fractions F14 (381-423, $90 \mathrm{mg}$ ) and F15 (424-455, $80 \mathrm{mg}$ ) were merged and $160 \mathrm{mg}$ were subjected to a Sephadex gel filtration. After a preparative TLC developed with c-hex/EtOAc (70/30: v/v), the subfraction 17-27 (12.3 mg) afford to compounds $10(2 \mathrm{mg})$ and 12 (1.8 mg). Subfractions 28-43 (20.6 mg) led to compound 12 (1 mg) after purification on a preparative TLC developed with c-hex/EtOAc (60/40: v/v). The fraction F16 (456-484, $140 \mathrm{mg}$ ) was subjected to a silica gel column (granulometry 40-63 $\mu \mathrm{m}$ ). Subfractions 28-130 (10.2 mg) were subjected to a preparative TLC developed with c-hex/ EtOAc (60/40: v/v) to led compound 10 (1.4 mg). Compound $13(1.5 \mathrm{mg})$ was isolated from the subfractions $131-$ 280 (10.3 mg) in the preparative TLC developed with chex/EtOAc (40/60: v/v).

\section{UHPLC-LTQ-Orbitrap Analysis of Millettia macrophylla phenolic fraction}

The analysis of the phenolic fraction of Millettia macrophylla was performed using an Accela Ultra HighPerformance Liquid Chromatography (UHPLC) system equipped with a mixing pump, an autosampler, and hyphenated to a hybrid LTQ-Orbitrap Discovery Mass Spectrometer (Thermo Scientific, Bremen, Germany). Stock solution of $100 \mu \mathrm{g} / \mathrm{mL}(\mathrm{MeOH} / \mathrm{H} 2 \mathrm{O}, 50 / 50$, v/v) of the fraction was prepared and $10 \mu \mathrm{L}$ injected on a Hypersil Gold column $(100 \times 2.1 \mathrm{~mm}$ i.d., $3 \mathrm{~mm})$ particle size, Thermo Scientific, Waltham, MA). The mobile phase used was aqueous acetic acid $0.1 \%(\mathrm{v} / \mathrm{v})$ (solvent A) and acetonitrile (solvent B). The initial conditions were $98 \%$ of solvent $\mathrm{A}$ and $2 \%$ of solvent $\mathrm{B}$ adjusting linearly to $98 \% \mathrm{~B}$ in $18 \mathrm{~min}$. This solvent composition was maintained for $0.9 \min (98 \% \mathrm{~B})$ followed by a return to the initial conditions (in $0.1 \mathrm{~min}$ ) and a reequilibration step $(1 \mathrm{~min})$ prior to the next run. The flow rate was set to $500 \mu \mathrm{L} / \mathrm{min}$.

The mass spectrometer was equipped with electrospray ionization (ESI) source and activated in a positive mode. The analysis was performed in full scan acquisition and the mass tolerance was set to $5 \mathrm{ppm}$ for all measurements. The ESI source was operated at a sheath gas flow rate of $50 \mathrm{arb}$, auxiliary gas flow rate of $10 \mathrm{arb}$, ion spray voltage of $3.5 \mathrm{kV}$, capillary temperature of $300{ }^{\circ} \mathrm{C}$, capillary voltage of $35 \mathrm{~V}$, tube lens of $110 \mathrm{~V}$. Xcalibur 2.0.7 software was used for the pre- and postacquisition of the results.

\section{General phytochemistry experimental procedures}

A Thermo Finnigan HPLC system (ThermoFinnigan, San Jose, CA) was employed for the profiling of the extract connected to a Spectral System UV2000 PDA detector. ChromQuest 2.1 software was used for the management of the data. Nuclear magnetic resonance (NMR) spectra were obtained on Bruker $600 \mathrm{MHz}$ spectrometer using $\mathrm{CDCl} 3$ (Sigma Aldrich, Germany) as solvent. The 2D-NMR experiments (COSY, LRCOSY, HMQC, HSQC-DEPT135, and HMBC) were performed using standard Bruker microprograms. ESI-HRMS were run on a Thermo Scientific LTQ Orbitrap Discovery mass spectrometer. GC-MS analyses were carried out using a Hewlett-Packard 5973-6890 GC-MS system operating in the EI mode at $70 \mathrm{eV}$, equipped with an HP-5 MS capillary silica column $(30 \mathrm{~m} \times 0.25 \mathrm{~mm}$ i.d.; $0.25 \mu \mathrm{m}$ film thickness). Sephadex LH-20 (Merck, Germany) was used as gel filtrate. Precoated TLC silica 60 F254 plates (Sigma Aldrich, Germany) were used for thin-layer chromatography $(0.25$ and $2 \mathrm{~mm}$ layer thickness for analytical and preparative TLC, respectively). Spots were visualized using UV light and vanillin-sulfuric acid reagent. 


\section{Chemicals}

Serum and antibiotics were purchased from GIBCO (Grand Island, NY). The 17 $\beta$-estradiol benzoate (Estr-1,3,5(10)trien-3,16 $\alpha, 17 \beta$-triol) was obtained from Sigma-Aldrich (Hamburg, Germany). The 2-[4-(2-hydroxyethyl)piperazin1-yl]ethane sulfonic acid (HEPES) was purchased from Ludwig Biotecnologia Ltda (Alvorada, RS, Brazil). Trypan blue, Sulforodamine B, Alamar blue and cell culture mediums were purchased from Sigma-Aldrich (St. Louis, MO, USA). Genistein was obtained from "Extrasynthese ${ }^{\text {" }}$ (Genay, France). Penicillin (xtapen ${ }^{\circledR}$ ) was provided by CSPC Zhongnuo pharmaceutical (Shijiazhuang City, China). Diclofenac (Dicloecnu ${ }^{\odot}$ ) was provided by ECNU pharmaceutical (Yanzhou City, China). The Smart Button Data loggers were purchased from ACR System Inc (Surrey, Canada).

\section{Experimental organisms \\ Cell line systems}

The MCF-7 - Human ER-positive breast adenocarcinoma cells and the MDA-MB-231- human ER-negative breast adenocarcinoma cells were obtained from the Rio de Janeiro Cell Bank (Federal University of Rio de Janeiro, Brazil).

HEK293T - Human Embryonic Kidney 293 T cells line that contain the SV40 large T-antigen were purchased from ATCC (The Global Bioresource Center, Australia). Luciferase reporter construct, ER $\alpha$ and ER $\beta$ expression plasmids were kindly provided by Dr Simon Chu (Hudson Institute of Medical Research, Australia). Cells were transfected using Lipofectamine Reagent obtained from Invitrogen (Sydney, Australia).

\section{Animals}

Healthy juvenile female Wistar rats aged 3 months ( 150 g) were obtained from the breeding facility of the Laboratory of Animal Physiology, University of Yaounde I (Cameroon). Animals were housed in clean plastic cages at room temperature (around $25{ }^{\circ} \mathrm{C}$ ) under natural illumination (approx. $12 \mathrm{~h}$ light/dark). They had free access to a standard soy-free rat chow and water ad libitum. The composition of animal diet was: corn (36.7\%), bone flour (14.5\%), wheat (36.6\%), fish flour (4.8\%), crushed palm kernel (7.3\%), sodium chloride $(0.3 \%)$ and vitamin complex (Olivitazol ${ }^{\bullet}$ $0.01 \%)$.

\section{Ethical consideration}

Housing of animals and all experiments were approved by the Cameroon Institutional National Ethic Committee, which adopted all procedures recommended by the European Union on the protection of animals used for scientific purposes (CEE Council 86/609; Reg. no. FWAIRD 0001954).

\section{In vitro experiments}

\section{Cell culture}

MDA-MB-231 cells were cultured in DMEM medium supplemented with $10 \%$ of fetal bovine serum (FBS). MCF-7 cells were cultured in RPMI-1640 medium supplemented with $10 \%$ of FBS. HEK293T cells were cultured in DMEM medium supplemented with $10 \%$ fetal calf serum (FCS). All cell cultures were also supplemented with $100 \mathrm{U} / \mathrm{mL}$ penicillin, $100 \mu \mathrm{g} / \mathrm{mL}$ streptomycin and $10 \mathrm{mM}$ HEPES. The cell cultures were maintained at $37{ }^{\circ} \mathrm{C}$ in a $5 \% \mathrm{CO}_{2}$ humidified atmosphere and $\mathrm{pH}$ 7.4. Every two days, cells were passaged by removing $90 \%$ of the supernatant and replacing it with fresh medium. In all experiments, viable cells were checked at the beginning of the experiment by Trypan Blue dye exclusion test.

\section{Cell viability assay}

Cytotoxicity potentials of isolates from M. macrophylla as well as phenolic fraction were evaluated by Alamar Blue (resazurin) assay [22], in two independent cellular systems (MCF-7 and MDA-MB-231). To evaluate the influence of concentration and time on cytotoxicity, $1 \times 10^{4}$ cells/well were seeded in a 96-well plate in $100 \mu \mathrm{L}$ of culture medium. After $24 \mathrm{~h}$ to permit their adhesion, cells were exposed to the 13 compounds isolated from $M$. macrophylla (1 to 13) at concentrations ranging from 100 to $500 \mu \mathrm{M}$. M. macrophylla phenolic fraction (PF) was also tested at concentrations of 100 and $500 \mu \mathrm{g} / \mathrm{mL}$ for $24 \mathrm{~h}$. The $\mathrm{CC}_{50}$ value (cytotoxic concentration, which means concentration required to reduce the cell number by $50 \%$ ) was determined only with promising compound by nonlinear regression analysis of the logarithm of concentration in function of the normalized response (percentage of cell viability) using the software GraphPad Prism 5.0. Each experiment was performed in at least triplicate and repeated three times.

\section{E-screen assay}

In order to evaluate estrogenic-like effects of isolates from M. macrophylla a simple and sensitive E-screen cell proliferation assay was performed with human ER-positive breast adenocarcinoma cells (MCF-7). This assay determines the estrogenicity/antiestrogenicity of compounds indirectly through measurement of the proliferation of MCF-7 cells. For this purpose, the technique slightly modified by Resende et al. [23], from the originally described by Soto et al. [24] was used. Briefly, cells were trypsinized and seeded in 24-well plates at an initial concentration of 20,000 cells per well in $10 \%$ FBS in RPMI. After $24 \mathrm{~h}$ of incubation $\left(37{ }^{\circ} \mathrm{C}, 5 \% \mathrm{CO}_{2}\right)$ to permit their adhesion, cells were washed with phosphate-buffered saline (PBS) and the Serum Replacement $2(0.5 \times)$ supplemented phenol red-free RPMI was substituted for the seeding medium. 
M. macrophylla compounds were added to the experimental medium at concentrations from 0.1 to $10 \mu \mathrm{M}$. For antiestrogenicity tests, before incubation, $1 \times 10^{-8} \mathrm{M}$ of $17 \beta$-estradiol was added to the wells. Steroid-free experimental medium consisted to negative control while cells treated with $1 \times 10^{-8} \mathrm{M}$ of $17 \beta$-estradiol served as positive control. There were also a solvent control (DMSO at $0.01 \%$ ) and a medium control (10 \% FBS in RPMI). The assay was stopped after $144 \mathrm{~h}$ by removing the medium from wells, fixing the cells, and staining them with sulforhodamine-B (SRB). Briefly, cells were treated with cold $10 \%$ trichloracetic acid and incubated at $4{ }^{\circ} \mathrm{C}$ for $1 \mathrm{~h}$. Then, the cells were washed four times with tap water and dried. Furthermore, cells were stained during $30 \mathrm{~min}$ with $0.057 \%(\mathrm{w} / \mathrm{v})$ SRB dissolved in $1 \%$ acetic acid. Wells were rinsed four times with $1 \%$ acetic acid and air dried. Bound dye was solubilized with $10 \mathrm{mM}$ Tris base ( $\mathrm{pH}$ 10.5) in a shaker. Finally, aliquots were read in a Biotek EL800 Multiscan apparatus (Winoosky, USA) at $510 \mathrm{~nm}$.

The results expressing the estrogenic activity were showed as mean \pm standard error of mean of the proliferative effect $(\mathrm{PE})$, which represents the maximum proliferation induced by the compounds. This parameter was calculated according to Schiliro'et al. [25], and is the ratio between the highest cell number achieved with the sample or $17 \beta$-estradiol and the cell number in the solvent control (0.01\% DMSO): PE = max cell number of sample/cell number of DMSO control.

The estrogenic activity of a sample was determined as the relative proliferative effect (RPE\%). The RPE compares the maximum proliferation induced by a sample with that induced by $17 \beta$-estradiol: $R P E \%=[P E$ for sample/PE for $17 \beta$-estradiol] $\times 100$ [23].

\section{Transfections and luciferase assays}

Due to the available quantity of isolates of $M$. macrophylla, only stigmastenone (3) and phenolic fraction (PF) has been deal with their capacity to activate estrogen receptors $\alpha$ and $\beta$, in cell-reporter gene assays. The Human Embryonic Kidney 293 T cell line (HEK293T) was transiently transfected with adequate plasmids using Lipofectamine Reagent as previously described by Zingue et al. [18]. They were then treated with different concentrations $\left[10^{-9}\right.$ to $10^{-5} \mathrm{M}$ for stigmastenone (3) and $10^{-5}$ to $10^{-1} \mu \mathrm{g} / \mathrm{mL}$ for phenolic fraction] for $24 \mathrm{~h}$. Cells treated with E2 (10 nM) alone served as positive control. Luciferase activity was measured and normalised against $\beta$-galactosidase activity as previously described [18].

\section{In vivo experiments}

\section{The 3-day uterotrophic assay}

To achieve this goal, 35 female Wistar rats received a single intramuscular dose of long acting penicillin and diclofenac
(10 $\mathrm{mg} / \mathrm{kg}$ and $3 \mathrm{mg} / \mathrm{kg}$ respectively) the day before ovariectomy. Thereafter they were bilaterally ovariectomized (OVX) using the dorsal approach [26] under Diazepam and ketamin anesthesia (respectively $10 \mathrm{mg} / \mathrm{kg}$ and $50 \mathrm{mg} / \mathrm{kg}$ BW; i.p.). After 14 days of endogenous hormonal decline, animals were randomly distributed into seven groups of five animals each $(n=5)$. The first group or OVX group received vehicle only (corn oil) and the second group received estradiol Benzoate (E2B) as standard drug at the optimal dose of $2 \mu \mathrm{g} / \mathrm{kg}$ per day. The third group received genistein at the dose of $10 \mathrm{mg} / \mathrm{kg}$. The remaining four groups received either the phenolic fraction (PF) at doses of 1,10 and $100 \mathrm{mg} / \mathrm{kg}$ or the methanol crude extract $(\mathrm{MeOH})$ of M. macrophylla at dose of $100 \mathrm{mg} / \mathrm{kg}$. All treatments were administered by subcutaneous route $(0.3 \mathrm{~mL} / 150 \mathrm{~g})$ for 3 days. Twenty-four hours after the last administration, animals were euthanized by decapitation. The uterine wet weight, total protein levels in uterine, uterine and vaginal epithelial heights and mammary gland were assessed as described before by Zingue et al. [20].

\section{Measurement of hot flushes}

Data loggers were used to monitor the core temperature changes in the animals at $2 \mathrm{~min}$ intervals for $72 \mathrm{~h}$, as previously described by Zingue et al. [27]. In this study, data loggers were preset to start measuring core temperatures $12 \mathrm{~h}$ before the beginning of the treatment until the end of treatment. Twenty acclimatized rats were either sham-operated (Sham) or bilaterally ovariectomized (OVX) as described above, and at the same time underwent the implantation of a data logger protected in sterilized neutral wax into their abdominal cavities. After 14 days of endogenous hormonal decline, animals were randomly distributed into four groups of five rats each $(n=5)$. They were treated for 3 days with corn oil as vehicle (OVX and Sham groups), estradiol benzoate (E2B) $(2 \mu \mathrm{g} / \mathrm{kg} \mathrm{BW}$ per day), and the active dose of the phenolic fraction $(10 \mathrm{mg} / \mathrm{kg} \mathrm{BW}$ per day). All treatment was given by subcutaneous route $(0.3 \mathrm{~mL} / 150 \mathrm{~g})$ and lasted 3 days. Twenty four hours after the last administration, animals were euthanized by decapitation, and the data loggers recovered. Data (central body temperature) was retrieved from loggers into excel spreadsheets and analyzed using the ACR Trend Reader for Smart Button Software. Hot flushes were considered for any internal temperatures $\geq 38^{\circ} \mathrm{C}$. The total number of hot flushes, the average of these hot flush durations and the frequency of hot flushes were determined as described before [27].

\section{Histological analysis}

Using the complete Zeiss equipment consisting of a microscope Axioskop 40 connected to a computer where the image was transferred, and analyzed with the MRGrab1.0 and Axio Vision 3.1 softwares, all provided by Zeiss (Hallbermoos, Germany), the histomorphology 
of the mammary glands, as well as the uterine and vaginal epithelial heights, were assessed from 5 - $\mu$ m sections of paraffin-embedded tissues following hematoxylineosin staining.

\section{Biochemical analysis}

Total uterine protein levels were determined in uteri using colorimetric methods described by Gonal et al. [28].

\section{Statistical analysis}

Results are presented as means \pm standard error of mean (SEM). In vitro experiments were performed in triplicates and repeated three times. All formulas and functions were calculated with Microsoft Excel software. Data analysis was performed with GraphPad Prism 5.0 software, using the ANOVA test followed by the Dunnett's post hoc test. Differences were considered significant at a probability level of $5 \%(p<0.05)$.

\section{Results}

Phytochemical analysis of M. macrophylla Identification of M. macrophylla isolates

A total of 13 secondary metabolites were isolated from M. macrophylla stem barks extracts. The structures of 1 , 2, and 5-13 were elucidated by $1 \mathrm{D} \& 2 \mathrm{D}$ NMR as well as HRMS and by comparison to previously reported data (Additional file 1). Compounds 3 and 4 structures were determined by GC-MS. The M. macrophylla isolates (Fig. 1) were identified as lupenone (1) [29], lupeol (2) [30], stigmastenone (3) [31], palmitic acid (4) [32], daidzein dimethylether (5) [33], formononetin (6) [34], afromorsin (7) [34], secundiferol I (8) [35], 2' hydroxyformononetin (9) [36], pisatin (10) [37], flemichapparin B (11) [38], dihydrocoumestrol dimethyl ether (12) [39] and variabilin (13) [40].

\section{UHPLC-LTQ-Orbitrap Analysis of Millettia macrophylla phenolic fraction}

The profiling of the phenolic fraction of Millettia macrophylla revealed the presence of the several secondary metabolites covering a wide polarity range (Fig. 2). Amongst others, 12 compounds could be tentatively identified. Chromatographic and spectrometric features such as retention time (Rt), high resolution quasimolecular ion (HRMS, $m / z$ ), suggested elemental composition, Ring Double Bond equivalent (RDBeq) were incorporated to the identification procedure. Specifically, six isoflavonoids (daidzein, daidzein dimethyl ether, biochanin A, 7-methyl tectorigenin, formononetin, afromorsin), three pterocarpans (maackiain, pisatin, flemichapparin B), one coumestan (coumestrol methyl ether), and one simple phenolic (2,4,6-Trimethoxyphenol) could be detected (Table 1). However, three compounds initially isolated from the phenolic fraction namely secundiflorol I, glycinol dimethyl ether, and dihydro-coumestrol dimethyl ether were not identified in the UHPLC-MS profile probably due to their minor concentration in the whole fraction.

\section{Effects of M. macrophylla isolates on cell viability}

The cytotoxic potential of $M$. macrophylla isolates is depicted in Table 2. No cytotoxic effects were found with compounds 1, 3-5, 9-12 up to $500 \mu \mathrm{M}$ in both MCF-7 and MDA-MB-231 cells. However, only 2 $(110 \mu \mathrm{M})$ and PF $(452 \mu \mathrm{g} / \mathrm{mL})$ induced a reduction of $50 \%$ of MCF-7 cells viability. MDA-MB-231 cells were more sensitive to the isolates than MCF-7 cells. $\mathrm{CC}_{50}$ values of $2,6,7,8,13$ and $\mathrm{PF}$ against MDAMB-231 cells were $160 \mu \mathrm{M}, 342 \mu \mathrm{M}, 224 \mu \mathrm{M}$, $457 \mu \mathrm{M}, 296 \mu \mathrm{M}$, and $327 \mu \mathrm{g} / \mathrm{mL}$, respectively.

\section{In vitro estrogenic effects of M. macrophylla isolates E-screen assay}

Results of the in vitro estrogenic potencies of $M$. macrophylla isolates are illustrated in Table 3 and Fig. 3. Lupeol (2), stigmastenone (3), formononetin (6), afromorsin (7), pisatin (10), flemichaparin B (11), variabilin (13) and phenolic fraction (PF) of $M$. macrophylla induced a significant $(p<0.05$ to $p<0.001)$ proliferation of MCF-7 cells such as $17 \beta$-estradiol $(p<0.001)$ as compared to DMSO control. Moreover, the rank order of the ability of these compounds to induce MCF-7 proliferation was: $13>7>10>3>11>$ $6>2>$ phenolic fraction. Although it has been observed decreased of MCF-7 cells yield with increasing concentration of compounds, no significant antiestrogenic effect was observed in this assay (data not shown).

\section{Luciferase assay}

It was found in this work that stigmastenone (3) significantly $(p<0.01)$ transactivated the ER $\alpha$ only at the concentration of $10^{-9} \mathrm{M}$ and this transactivation seems to decrease while its concentration rises up (Fig. 4a). In other hand, 3 failed to transactivated or antagonized the estrogen activity on ER $\beta$ (Fig. 4b). As far as M. macrophylla phenolic fraction is concerned, it induced a significant transactivation of the ER $\alpha$ as well as the ER $\beta$ at concentrations of $10^{-3}(p<0.01)$ and $10^{-2} \mu \mathrm{g} / \mathrm{mL}(p<$ $0.001)$, while this effect disappear at the concentration of $10^{-1} \mu \mathrm{g} / \mathrm{mL}$ (Fig. 4c). Moreover, the phenolic fraction of M. macrophylla seems to be antagonistic to E2 at the lower $\left(10^{-5}\right.$ and $\left.10^{-4} \mu \mathrm{g} / \mathrm{mL}\right)$ and higher $\left(10^{-1} \mu \mathrm{g} / \mathrm{mL}\right)$ concentrations, while it exhibited a synergistic activity with E2 at the concentration of $10^{-2} \mu \mathrm{g} / \mathrm{mL}$ in HEK293T-ER $\alpha$. A significant $(p<0.001)$ antiestrogenic activity was also observed with the phenolic fraction of M. macrophylla on HEK293T-ER $\beta$ at the concentration of $10^{-2} \mu \mathrm{g} / \mathrm{mL}$ (Fig. $4 \mathrm{~d}$ ). 


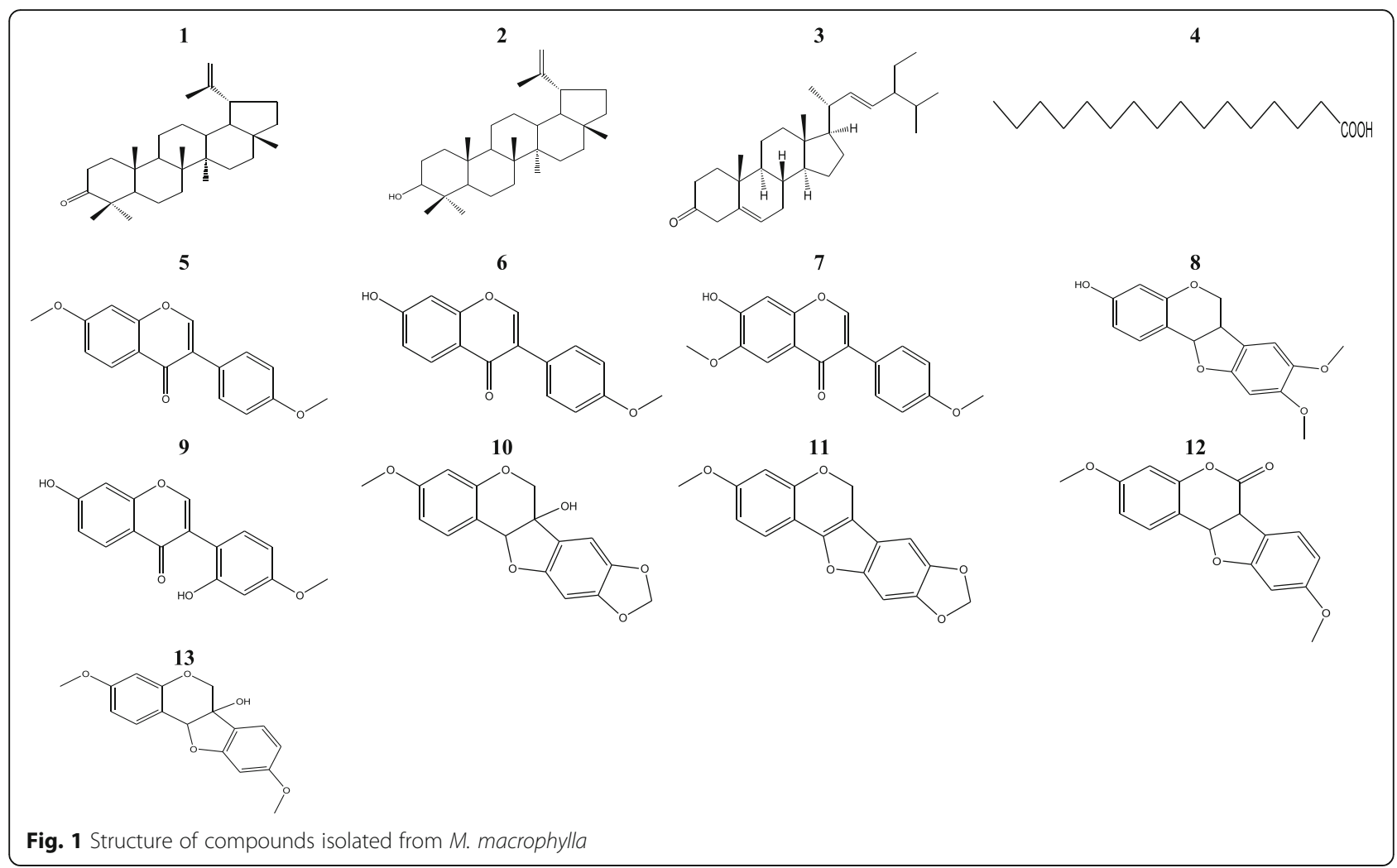

\section{In vivo estrogenic effects of M. macrophylla phenolic fraction \\ Effects on uterus}

Figure 5 showed that E2B induced a significant increase $(p<0.001)$ in the uterine wet weight (Fig. 5a) as well as total protein levels in the uterus (Fig. $5 \mathrm{~b}$ ) as compared to the OVX group. Genistein at the dose of $10 \mathrm{mg} / \mathrm{kg}$ did not increase the uterine wet weight while it induced a non-significant increase in uterine total protein levels. The phenolic fraction led to a significant increase $(p<$ $0.05)$ in the uterine wet weight $(693.31 \pm 52.04$ vs 399.31 $\pm 31.12 \mathrm{mg} / \mathrm{kg}$ in OVX group) only at the dose of $10 \mathrm{mg} / \mathrm{kg}$ and in the uterine total protein level at the dose of $10(4.0 \pm 0.54$ vs $3.1 \pm 0.02 \mathrm{mg} / \mathrm{mL}$ in OVX group) and $100 \mathrm{mg} / \mathrm{kg}(3.6 \pm 0.08$ vs $3.1 \pm 0.02 \mathrm{mg} / \mathrm{mL}$ in OVX group), while the methanol crude extract did not changes the uterine wet weight.

Figure 5d represents the micrographs of the uterus following 3 days of treatment with different substances. It can be observed that the uterine epithelium of OVX animals consisted to one layer of very flattened cuboidal cells while, animals treated for 3 days with E2B present epithelium composed with large columnar cells. The measurements of the uterine epithelia height showed that the E2B and genistein induced a significant increase $(p<0.001$ and $p<0.01)$ (Fig. 5c) as compared to the

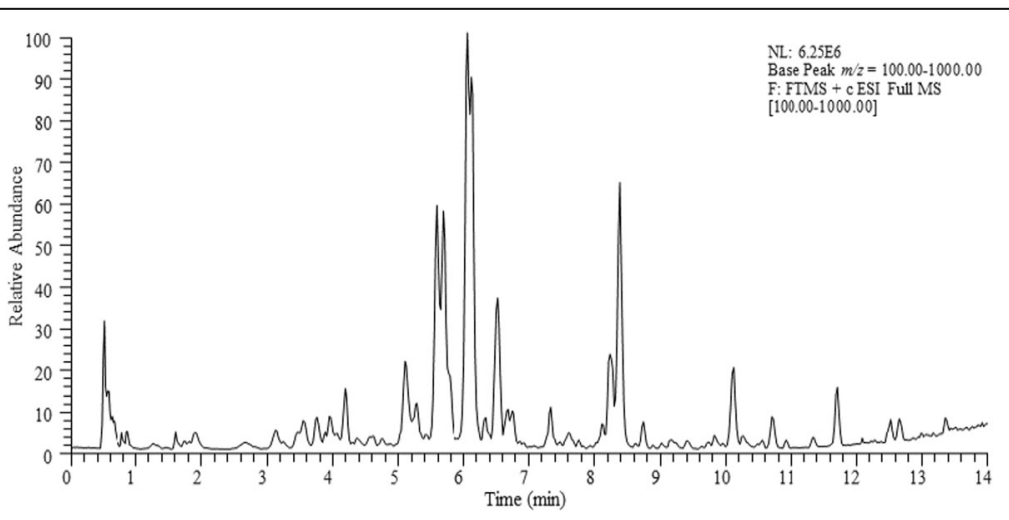

Fig. 2 Base peak chromatogram of Millettia macrophylla phenolic fraction recorded in UHPLC-ESI (+)-LTQ-Orbitrap 
Table 1 Chromatographic and spectrometric characteristics of secondary metabolites identified in Millettia macrophylla phenolic fraction using UHPLC-ESI (+)-LTQ-Orbitrap

\begin{tabular}{|c|c|c|c|c|c|c|c|}
\hline Peak & Rt (min) & Experimental $\mathrm{m} / \mathrm{z}$ & Theoretical $\mathrm{m} / \mathrm{z}$ & $\Delta(\mathrm{ppm})$ & $\mathrm{RDB}$ & {$[\mathrm{M}+\mathrm{H}]^{+}$} & Assignment \\
\hline 1 & 1.61 & 185.0804 & 185.0808 & -2.352 & 3.5 & $\mathrm{C}_{9} \mathrm{H}_{13} \mathrm{O}_{4}$ & 2,4,6-Trimethoxyphenol \\
\hline 2 & 2.81 & 255.0646 & 255.0652 & -2.452 & 10.5 & $\mathrm{C}_{15} \mathrm{H}_{11} \mathrm{O}_{4}$ & Daidzein \\
\hline 3 & 3.97 & 285.0750 & 285.0757 & -2.491 & 10.5 & $\mathrm{C}_{16} \mathrm{H}_{13} \mathrm{O}_{5}$ & Maackiain \\
\hline 4 & 6.53 & 285.0753 & 285.0757 & -1.614 & 10.5 & $\mathrm{C}_{16} \mathrm{H}_{13} \mathrm{O}_{5}$ & Biochanin A \\
\hline 5 & 6.69 & 315.0856 & 315.0863 & -2.173 & 10.5 & $\mathrm{C}_{17} \mathrm{H}_{15} \mathrm{O}_{6}$ & Pisatin \\
\hline 6 & 7.68 & 315.0855 & 315.0863 & -2.649 & 10.5 & $\mathrm{C}_{17} \mathrm{H}_{15} \mathrm{O}_{6}$ & 7-Methyl tectorigenin \\
\hline 7 & 8.24 & 269.0801 & 269.0808 & -2.696 & 10.5 & $\mathrm{C}_{16} \mathrm{H}_{13} \mathrm{O}_{4}$ & Formononetin \\
\hline 8 & 8.39 & 299.0908 & 299.0965 & -1.939 & 10.5 & $\mathrm{C}_{17} \mathrm{H}_{15} \mathrm{O}_{5}$ & Afromorsin \\
\hline 9 & 8.75 & 297.0751 & 297.0757 & -2.289 & 11.5 & $\mathrm{C}_{17} \mathrm{H}_{13} \mathrm{O}_{5}$ & Flemichapparin B \\
\hline 10 & 10.12 & 283.0957 & 283.0965 & -2.775 & 10.5 & $\mathrm{C}_{17} \mathrm{H}_{15} \mathrm{O}_{4}$ & Daidzein dimethyl ether \\
\hline 11 & 10.70 & 283.0594 & 283.0601 & -2.508 & 11.5 & $\mathrm{C}_{16} \mathrm{H}_{11} \mathrm{O}_{5}$ & Coumestrol methyl ether \\
\hline
\end{tabular}

OVX group. M. macrophylla phenolic fraction has increased uterine epithelium height $(6.15 \pm 0.87$ vs $3.54 \pm$ $0.21 \mu \mathrm{m} ; p<0.01)$ at the dose of $10 \mathrm{mg} / \mathrm{kg}$ more than methanol extract at the dose of $100 \mathrm{mg} / \mathrm{kg}(5.68 \pm 0.32 \mathrm{vs}$ $3.54 \pm 0.21 \mu \mathrm{m}, p<0.05)$ as compared to the OVX group.

\section{Effects on vagina}

Analysis of vagina's microphotographs from different treatment groups are shown in Fig. 6a. The vagina epithelium of OVX animals is limited to the germinal layer (Ge), consisting of 5-6 cell layers, whereas the vaginal epithelium of animals treated for 3 days with E2B became stratified. Similar stratification coupled with vaginal cornification was observed also in animals treated with the phenolic fraction at the dose of $10 \mathrm{mg} / \mathrm{kg}(p<$ $0.01)$. Furthermore, the measurement of vaginal epithelial height in different treated groups showed that the E2B induced a significant increase $(p<0.001)$ in the vaginal epithelial height as compared to the OVX group (Fig. 6b). A significant increase in the vaginal epithelium height was observed after administrating PF at doses of 10 and $100 \mathrm{mg} / \mathrm{kg}$ as well as the methanol extract of $M$. macrophylla at the dose of $100 \mathrm{mg} / \mathrm{kg}$. However it can be noted that the increment induced by phenolic fraction $(15.63 \pm 3.46$ vs $4.47 \pm 0.51 \mu \mathrm{m}, p<0.01)$ was greater than that observed with the methanol extract $(13.61 \pm$ 1.02 vs $4.47 \pm 0.51 \mu \mathrm{m}, p<0.05)$ as compared to the OVX group.

Table 2 Cytotoxicity of isolates of M. macrophylla as well as phenolic fraction toward breast cancer cells

\begin{tabular}{|c|c|c|c|}
\hline \multirow[b]{2}{*}{ Code } & \multirow[b]{2}{*}{ Name of compounds } & \multicolumn{2}{|l|}{ CC50 } \\
\hline & & MCF-7 cells & MDA-MB-231 cells \\
\hline 1 & lupenone & $>500$ & $>500$ \\
\hline 2 & lupeol & 110 & 160 \\
\hline 3 & stigmastenone & $>500$ & $>500$ \\
\hline 4 & palmitic acid & $>500$ & $>500$ \\
\hline 5 & daidzein dimethylether & $>500$ & $>500$ \\
\hline 6 & formononetin & $>500$ & 342 \\
\hline 7 & afromorsin & $>500$ & 224 \\
\hline 8 & secundiferol I & $>500$ & 457 \\
\hline $92^{\prime}$ & $\mathrm{OH}$-formononetin & $>500$ & $>500$ \\
\hline 10 & $(+)$-pisatin & $>500$ & $>500$ \\
\hline 11 & flemichapparin B & $>500$ & $>500$ \\
\hline 12 & dihydrocoumestrol dimethylether & $>500$ & $>500$ \\
\hline 13 & variabilin & $>500$ & 296 \\
\hline PF & phenolic fraction & 452 & 327 \\
\hline
\end{tabular}

MCF-7 and MDA-MB-231 cells were incubated with increasing concentration (100-500 $\mu \mathrm{M})$ of isolates of $M$. macrophylla and phenolic fraction -PF (100-500 $\mu \mathrm{g} / \mathrm{mL})$ for $24 \mathrm{~h}$. Cell viability was evaluated by Alamar blue assay. The CC50 was determined when applicable by nonlinear regression analysis of the logarithm of concentration in function of the normalized response (percentage of cell viability). Values are in $\mu \mathrm{M}$ or $\mu \mathrm{g} / \mathrm{mL}$ mean of three independent experiments. The Bold data reflect the exact cytotoxic concentration $\left(\mathrm{CC}_{50}\right)$ 
Table 3 Effects of isolates of M. macrophylla in MCF-7 cells proliferation assay

\begin{tabular}{|c|c|c|c|c|}
\hline Code & Name of compounds & Concentration & PE & RPE (\%) \\
\hline DMSO & Control & - & 1 & 54.2 \\
\hline E2B & $17 \beta$-estradiol & $10 \mathrm{nM}$ & 1.84 & 100 \\
\hline \multirow[t]{3}{*}{1} & \multirow[t]{3}{*}{ Lupenone } & $0.1 \mu \mathrm{M}$ & 1.38 & 75 \\
\hline & & $1 \mu \mathrm{M}$ & 1.22 & 66.48 \\
\hline & & $10 \mu \mathrm{M}$ & 0.47 & 25.53 \\
\hline \multirow[t]{3}{*}{2} & \multirow[t]{3}{*}{ lupeol } & $0.1 \mu \mathrm{M}$ & 1.52 & 82.45 \\
\hline & & $1 \mu \mathrm{M}$ & 1.26 & 68.62 \\
\hline & & $10 \mu \mathrm{M}$ & 1.19 & 64.36 \\
\hline \multirow[t]{3}{*}{3} & \multirow[t]{3}{*}{ stigmastenone } & $0.1 \mu \mathrm{M}$ & 1.63 & 88.30 \\
\hline & & $1 \mu \mathrm{M}$ & 1.29 & 70.21 \\
\hline & & $10 \mu \mathrm{M}$ & 0.76 & 41.49 \\
\hline \multirow[t]{3}{*}{4} & \multirow[t]{3}{*}{ palmitic acid } & $0.1 \mu \mathrm{M}$ & 1.36 & 73.94 \\
\hline & & $1 \mu \mathrm{M}$ & 1.13 & 61.17 \\
\hline & & $10 \mu \mathrm{M}$ & 0.65 & 35.11 \\
\hline \multirow[t]{3}{*}{5} & \multirow[t]{3}{*}{ daidzein dimethylether } & $0.1 \mu \mathrm{M}$ & 1.29 & 70.21 \\
\hline & & $1 \mu \mathrm{M}$ & 1.33 & 72.34 \\
\hline & & $10 \mu \mathrm{M}$ & 0.90 & 48.93 \\
\hline \multirow[t]{3}{*}{6} & \multirow[t]{3}{*}{ formononetin } & $0.1 \mu \mathrm{M}$ & 1.55 & 84.04 \\
\hline & & $1 \mu \mathrm{M}$ & 1.05 & 56.91 \\
\hline & & $10 \mu \mathrm{M}$ & 0.67 & 36.17 \\
\hline \multirow[t]{3}{*}{7} & \multirow[t]{3}{*}{ afromorsin } & $0.1 \mu \mathrm{M}$ & 1.83 & 99.47 \\
\hline & & $1 \mu \mathrm{M}$ & 1.21 & 65.96 \\
\hline & & $10 \mu \mathrm{M}$ & 0.66 & 35.64 \\
\hline \multirow[t]{3}{*}{8} & \multirow[t]{3}{*}{ secundiferol I } & $0.1 \mu \mathrm{M}$ & 1.17 & 63.83 \\
\hline & & $1 \mu \mathrm{M}$ & 1.33 & 72.34 \\
\hline & & $10 \mu \mathrm{M}$ & 0.68 & 36.70 \\
\hline \multirow[t]{3}{*}{9} & \multirow[t]{3}{*}{ 2' OH-formononetin } & $0.1 \mu \mathrm{M}$ & 1.08 & 58.51 \\
\hline & & $1 \mu \mathrm{M}$ & 0.99 & 53.72 \\
\hline & & $10 \mu \mathrm{M}$ & 0.65 & 35.11 \\
\hline \multirow[t]{3}{*}{10} & \multirow[t]{3}{*}{ pisatin } & $0.1 \mu \mathrm{M}$ & 1.70 & 92.02 \\
\hline & & $1 \mu \mathrm{M}$ & 1.21 & 65.96 \\
\hline & & $10 \mu \mathrm{M}$ & 0.66 & 35.64 \\
\hline \multirow[t]{3}{*}{11} & \multirow[t]{3}{*}{ flemichapparin B } & $0.1 \mu \mathrm{M}$ & 1.57 & 85.11 \\
\hline & & $1 \mu \mathrm{M}$ & 1.31 & 71.28 \\
\hline & & $10 \mu \mathrm{M}$ & 0.82 & 44.68 \\
\hline \multirow[t]{3}{*}{12} & \multirow[t]{3}{*}{ dihydrocoumestrol DME } & $0.1 \mu \mathrm{M}$ & 1.23 & 67.02 \\
\hline & & $1 \mu \mathrm{M}$ & 1.16 & 62.76 \\
\hline & & $10 \mu \mathrm{M}$ & 0.81 & 44.15 \\
\hline \multirow[t]{3}{*}{13} & \multirow[t]{3}{*}{ glycinol dimethylether } & $0.1 \mu \mathrm{M}$ & 2 & 108.51 \\
\hline & & $1 \mu \mathrm{M}$ & 1.38 & 75 \\
\hline & & $10 \mu \mathrm{M}$ & 0.88 & 47.87 \\
\hline
\end{tabular}

Table 3 Effects of isolates of M. macrophylla in MCF-7 cells proliferation assay (Continued)

\begin{tabular}{llll}
\hline PF Phenolic fraction & $0.1 \mu \mathrm{g} / \mathrm{mL}$ & 1.49 & $\mathbf{8 0 . 8 5}$ \\
& $1 \mu \mathrm{g} / \mathrm{mL}$ & 1.17 & 64.36 \\
& $10 \mu \mathrm{g} / \mathrm{mL}$ & 0.55 & 29.78 \\
\hline
\end{tabular}

$D M S O$ negative control, E2B positive control, $P E$ proliferative effect calculated as the effect on solvent control, RPE relative proliferative effect, compares the maximum proliferation induced by a sample with that induced by $17 \beta-$ estradiol. The Bold data represents the values considerate as estrogenic

\section{Effects on mammary gland}

The microphotographs of mammary glands (Fig. 7) revealed that OVX animals exhibited smaller acini with non-differentiate lumen of acini, low connective parenchyma while, adipose tissue is abundant. The E2B treatment induced an increase in the size of acini as well as the lumen of acini, which appear well differentiated compared to the OVX group. It can be also observed the presence of abundant eosinophil secretions in the lumen of the acini. The treatment with genistein induced such effects although the arising of the eosinophil secretions in the lumen of acini was low. As far as phenolic fraction and methanol extract of $M$. macrophylla are concerned, they induced an increase in the lumen of the acini at all tested doses as compared to OVX group. However eosinophil secretions were observed only in animal's group treated with phenolic fraction at the dose of $10 \mathrm{mg} / \mathrm{kg}$.

\section{Effects on hot flushes}

Two weeks after oophorectomy, the total number of hot flushes $(p<0.05$, Fig. $8 \mathrm{a})$ as well as the average duration of hot flushes $(p<0.01$; Fig. $8 \mathrm{~b})$ were significantly increased in the OVX group compared to the normal group (Sham). A significant decrease in the number $(p<$ $0.05)$ and in the average duration $(p<0.01)$ of hot flushes was observed in the E2B treated group. After 3 days of treatment, the phenolic fraction at the dose of $10 \mathrm{mg} / \mathrm{kg}$ induced a significant decrease $(p<0.05)$ in the average duration of hot flushes while, it failed to reduce the total number of hot flushes. As compared to the normal group (Sham), OVX animals showed a significant increase $(p<0.01)$ in the frequency of hot flushes (Fig. 8c). As expected, E2B induced a significant decrease $(p<0.01)$ in the frequency of hot flushes as compared to OVX group. Such effects were also observed with phenolic fraction of $M$. macrophylla at a dose of $10 \mathrm{mg} / \mathrm{kg}(p<0.01)$.

\section{Discussion}

In order to contribute to a better understanding of the previous reported estrogenic/antiestrogenic properties of M. macrophylla [18-20], its major components were isolated. As striking observation, it was noted that most 

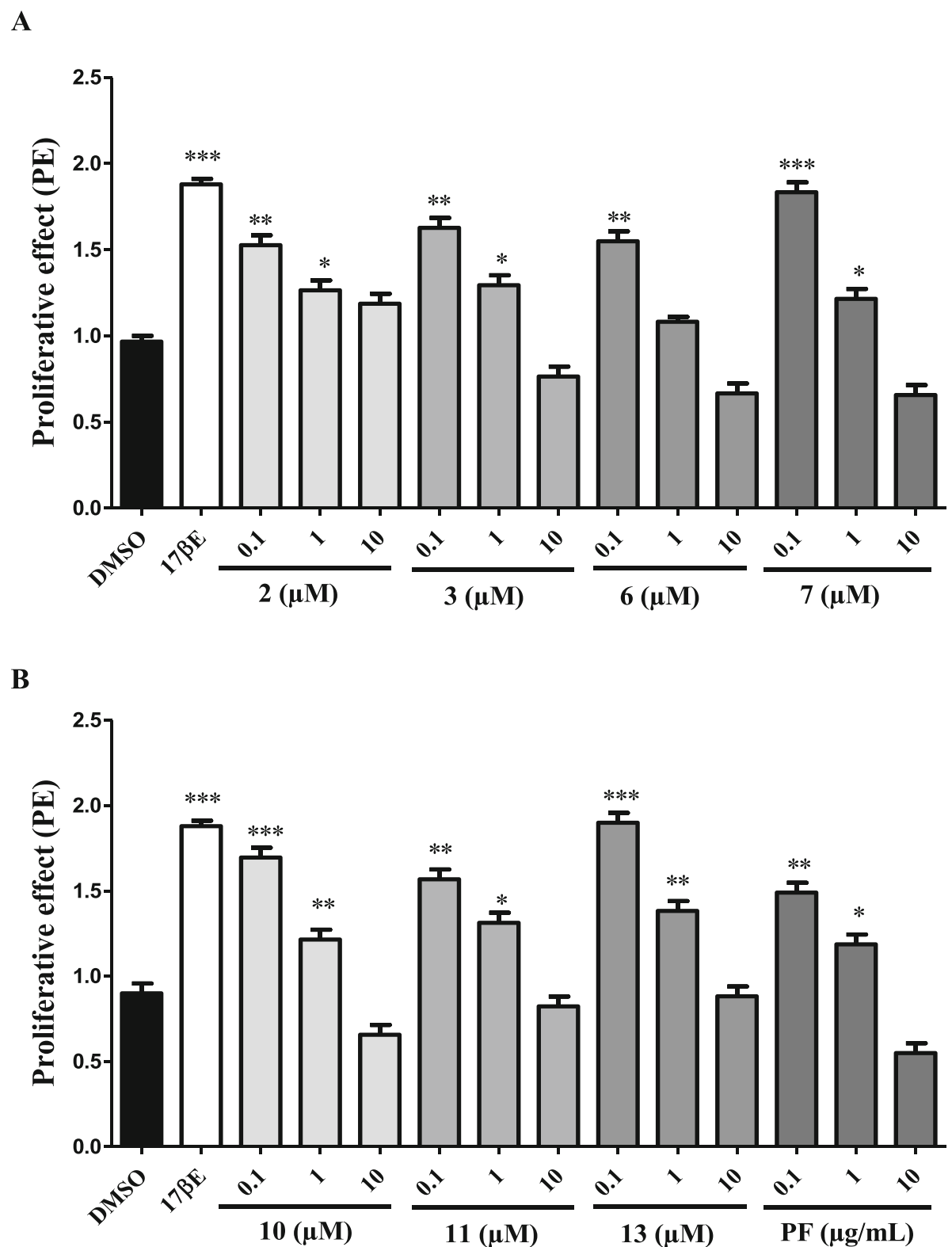

Fig. 3 Effects of lupeol (2), stigmastenone (3), formononetin (6), afromorsin (7) (a) and of pisatin (10), flemichapparin B (11), variabilin (13), phenolic fraction (PF) (b) from M. macrophylla on MCF-7 cells proliferation. The effect of compounds and phenolic fraction was investigated by measuring E-screen assay. The relative MCF-7 cells yields (PE) were measured in the presence of DMSO $(0.01 \%), 17 \beta$-estradiol (10 nM), compounds and phenolic fraction from M. macrophylla. PE = max cell number of sample/cell number of DMSO control. ${ }^{*} p<0.05,{ }^{* *} p<0.01,{ }^{* * *} p<0.001$ as compared with DMSO

of these compounds belonging to the flavonoids group, specifically, isoflavone, pterocarpan and coumestan subgroups, which are well known as phytoestrogens.

Although the uterotrophic assay in rodents is a good tool to assess estrogenic potency of xenobiotics, this method is not suitable for the screening of large suspected estrogenic chemicals [41]. We have therefore used the biologically equivalent E-screen assay described by Soto et al. [24] and modified by Resende et al. [23].
This assay compares the cell yield between cultures of MCF-7 cells treated with estradiol and cultures treated with different concentrations of substances suspected to endow estrogenic properties. It was noted in this study that 7 out of 13 isolated compounds from M. macrophylla induced MCF-7 cells proliferation such as $17 \beta$ estradiol in the following rank order: $13>7>10>3>$ $11>6>2>$ phenolic fraction. The E-screen assay measures the direct cell proliferation, which is acknowledged 

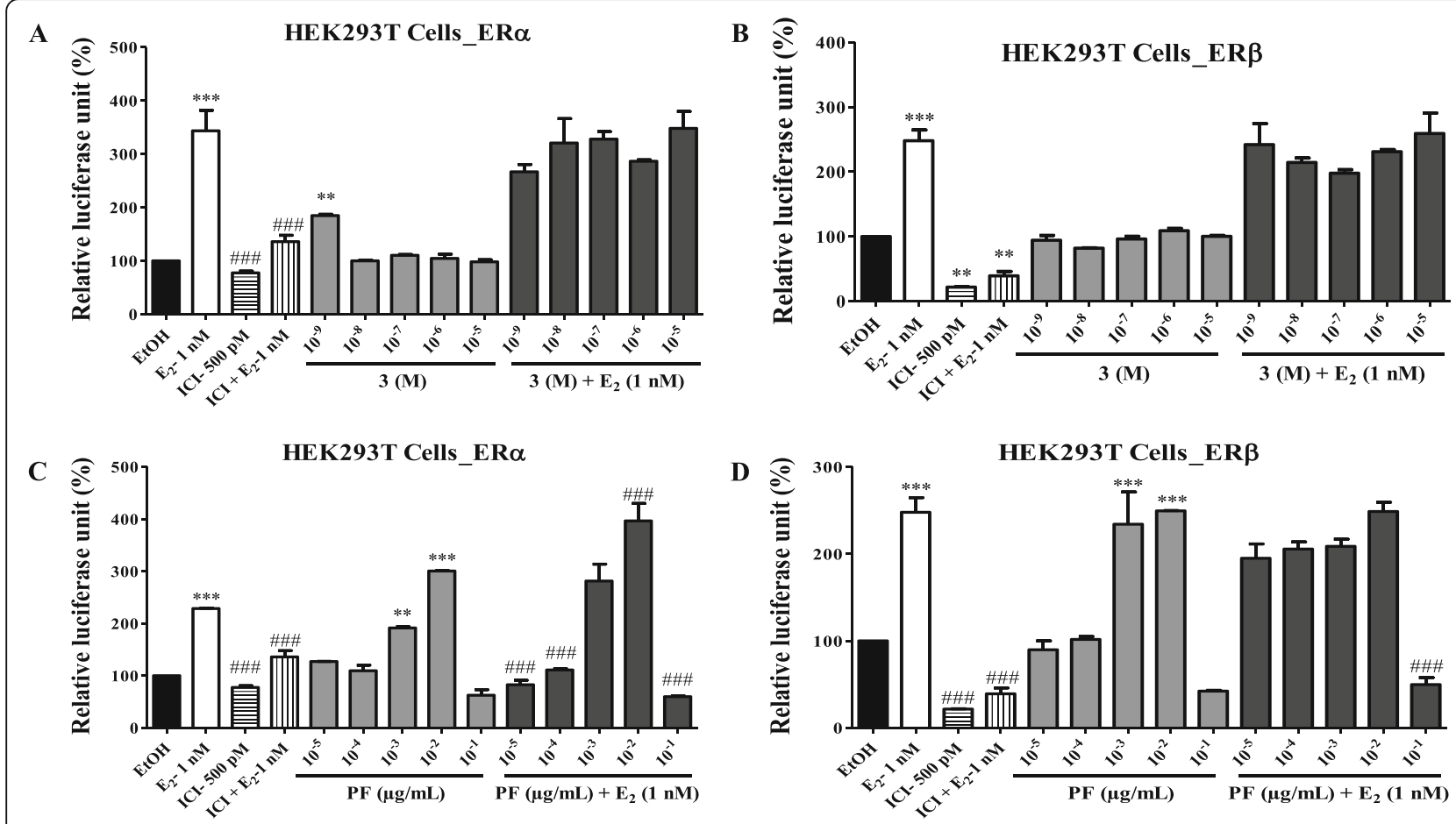

Fig. 4 Effects of stigmastenone (3) and M. macrophylla phenolic fraction (PF) on the activation of estrogen a and $\beta$ receptors in HEK293T cells. The effect of these substances on estrogen $a$ and $\beta$ receptors activity in the transiently transfected HEK293T-ERa and HEK293T-ER $\beta$ cells was investigated by measuring reporter gene-coupled luciferase activity. The relative luciferase units (RLU) were measured in the presence of EtOH (0.1\%), E2 (10 nM), stigmatenone (3) as well as M. macrophylla phenolic fraction co-treated with $\mathrm{E} 2 .{ }^{* *} p<0.01$; ${ }^{* * *} p<0.001$ as compared to EtOH control; \#\#\# $p<0.001$ as compared with E2 control

as hallmark of estrogenicity [24]. Indeed, the MCF-7 cells proliferation is the reliable estrogenic potency because this cell line is ER positive and it expresses aromatase and $5 \alpha-$ reductase enzymes, which allows it to convert androgens to estrogens $[23,41]$. These authors reported that a relative proliferative effect (RPE) $\geq 80$ corresponds to estrogenic activity and suggest that the compound may have agonistic activity to ER $\alpha$. However, it is worthwhile to highlight that the MCF-7 cells can elicit an estrogen-induced response involving both genomic and non-genomic pathways [25]. Hence, such as in in vivo condition, the MCF-7 cells proliferation observed in E-screen assay is not limited to the activation of ERs [23].

It is well documented that some chemical features in the structure of flavonoids are required to obtain an estrogenic response [42]. A particular note was aroused on the hydroxyl group at position 4' which promotes the estrogenic activity and the estrogenic potency [43]. Accordingly, the lack of free hydroxyl group at position 4' or $7^{\prime}$ in 5 might explain its weak affinity for ERs. Indeed, Khan et al. [44] showed that 3,4',-dimethoxy daidzein had no estrogenicity. This result is consistent with the observation made in this work with 5 . However, they reported that it endow positive skeletal effects in osteopenic rats. This might account for the preventive effect previously observed with $M$. macrophylla in postmenopausal osteoporosis [19]. The estrogenic activity of $M$. macrophylla could be explained in part by the presence of 6, which activates the expression of the estrogenresponsive reporter gene in human breast cell line MCF7 in a concentration-dependent manner $(0.5-500 \mu \mathrm{M})$. Moreover, this activation was inhibited by estrogen antagonist (ICI 182, 780 at $100 \mathrm{nM}$ ) [45]. Furthermore, authors have reported that formononetin induced the proliferation of MCF-7 breast cancer cells, which is consistent with our observations. Other compounds that might contribute to the estrogenicity of $M$. macrophylla are 13 and 10. In fact, 10 has been reported to have a weak affinity to ER $\alpha$ [46] while glycinol an analogue of 13 found in M. macrophylla displayed estrogenic effect by induction of MCF-7 cells proliferation at concentration ranging from 1 to $10 \mu \mathrm{M}$ [47]. These results are consistent with the obtained results with variabilin in this study. In addition, authors showed that glycinol has a high affinity for both $\mathrm{ER} \alpha\left(\mathrm{IC}_{50}=13.8 \mathrm{nM}\right)$ and $\mathrm{ER} \beta$ $\left(\mathrm{IC}_{50}=9.1 \mathrm{nM}\right) .11,3$ and 2 are described for the first time as estrogenic in this work. 11 is structure related to 10 , this can explain its estrogenic activity. As far as stigmastenone and lupeol are concerned, they are triterpernoids, and there is little reports in the literature dealing 


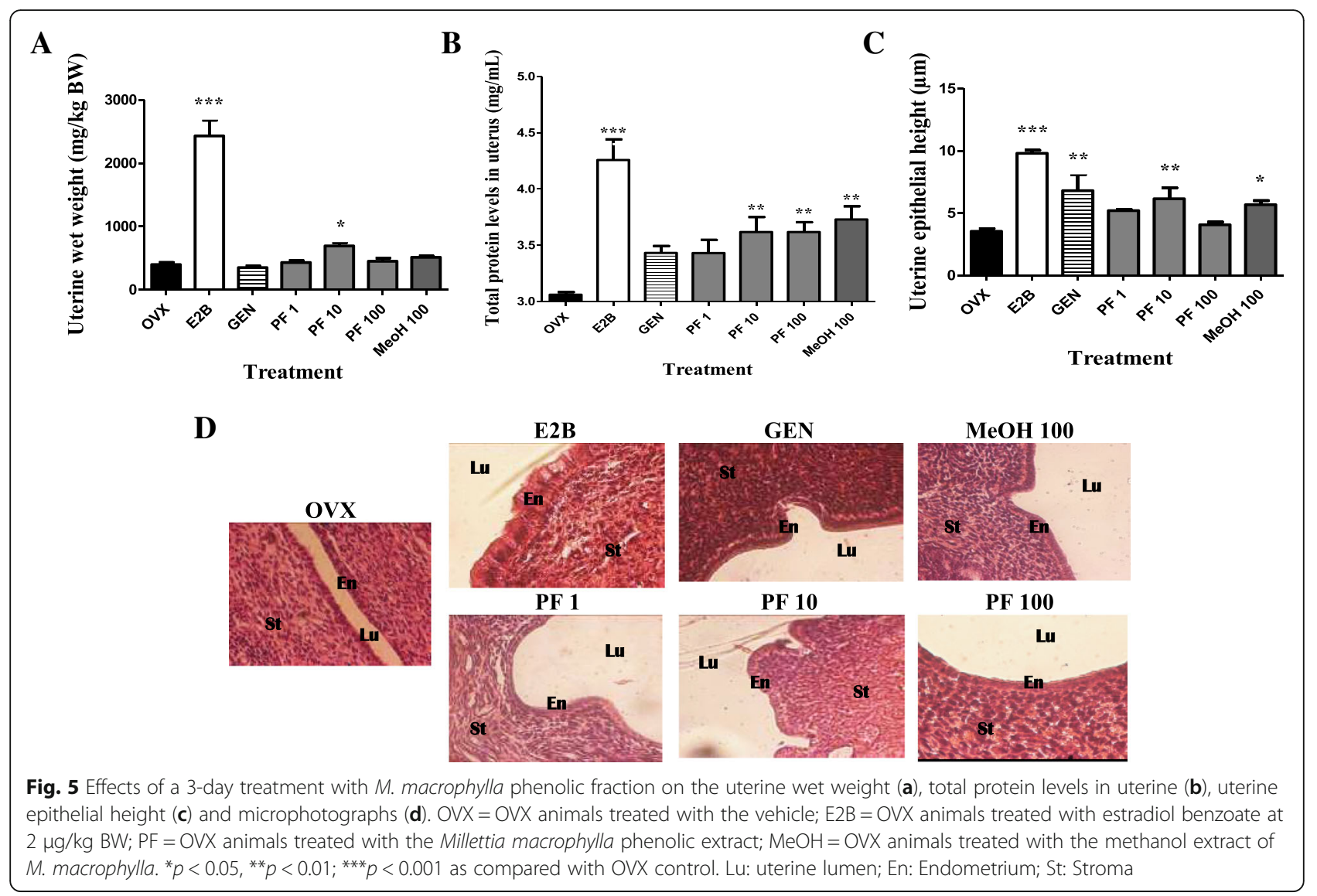

the estrogenic activity of triterpernoids. However, triterpernoid glycosyl such as glycyrrhizin and ginsenoside$\mathrm{Rh} 2$ have been reported to endow estrogenic properties [48]. Indeed, ginsenoside-Rh2 has been shown to transactivate the ER $\alpha$ in MCF-7, and its effect was abrogated by the pure antiestrogen faslodex (ICI 182,780), suggesting that its effects are primarily mediated by ERs [49]. It was observed a decrease in the proliferative effect of compounds with increasing concentrations (from 0.1 to $10 \mu \mathrm{M})$, while they did not induce cytotoxicity at concentration 10 fold higher, avoiding the hypothesis of the cytotoxicity at these concentrations. However, the results obtained with 3 in MCF-7 cells proliferation assay are in accordance with those observed in the reporter gene assay. In fact, such as in MCF-7 cells proliferation, it was noted a concentration-dependent decrease in the transactivation induced by 3 in ER $\alpha$. This result strongly suggests a down regulation phenomenon rather than a cytotoxicity of these compounds. This phenomenon is common with phytoestrogen [50]. In addition, belutin a triterpernoid, structurally related to 2 and 3 have shown estrogenic activity in MCF-7 cells [51]. It is noteworthy that 2 has osteogenic properties in vitro [52]; which can account for beneficial effects of $M$. macrophylla in postmenopausal osteoporosis.
Besides their estrogenic properties, phytoestrogens exert a wide variety of pharmacological effects including cytotoxicity [10]. Estrogen receptors are one of the targets in anti-breast cancer therapy. For this reason the cytotoxic potential of compounds from M. macrophylla was assessed. It was noted that 2 induced cytotoxic effects on MCF-7 $\left(\mathrm{CC}_{50}=110 \mu \mathrm{M}\right)$ and MDA-MB-231 $\left(\mathrm{CC}_{50}=160 \mu \mathrm{M}\right)$ cells. This result is in accordance with some reports $[53,54]$. Weak cytotoxic effects were also observed with $6,7,8,13$ and PF. These results are consistent with some reports which postulate that phytoestrogens may exert two opposite actions depending on their concentrations [55]. At lower concentrations $(<10 \mu \mathrm{M})$, some phytoestrogens, like genistein, stimulate growth of ER positive MCF-7 cells, but not the ER negative MDA-MB-231 breast cancer cells. At higher concentrations survival of both types of breast cancer cells decreases. It was postulate that at the lower concentration, phytoestrogens acted as ligands of ERs and stimulate metabolic pathways, which in turn induced cell proliferation. However, at higher concentrations, mechanisms which are not dependent on ER pathway such as antioxidant properties of the flavonoids seem to be triggered [55]. The above arguments might also explain why MDA-MB-231 cells were found most sensitive than 


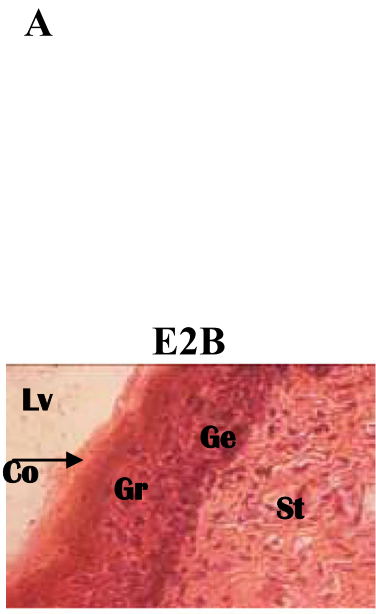

PF 1

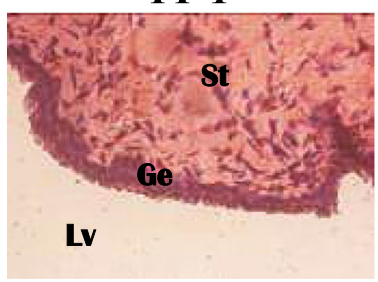

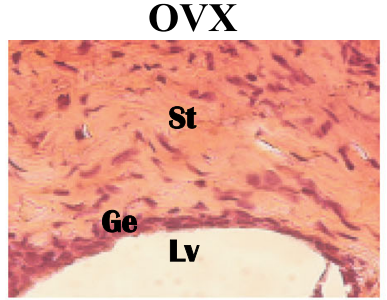

GEN

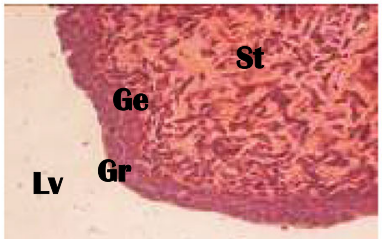

PF 10

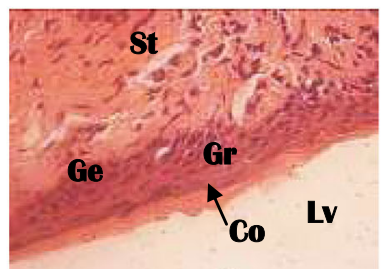

B

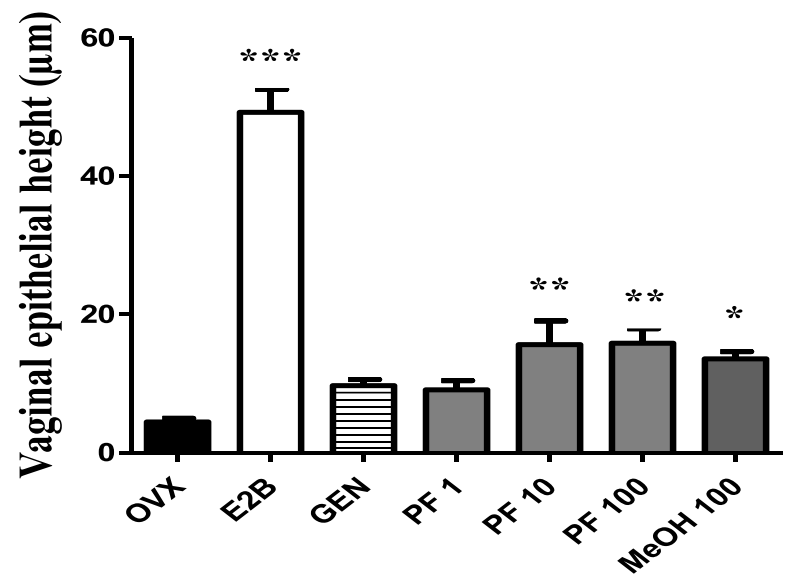

Treatment

Fig. 6 Effects of a 3-day treatment with Millettia macrophylla phenolic fraction on the vaginal epithelium: microphotographs (a) and epithelial height (b). $\mathrm{OVX}=\mathrm{OVX}$ animals treated with the vehicle; $\mathrm{E} 2 \mathrm{~B}=\mathrm{OVX}$ animals treated with estradiol benzoate at $2 \mu \mathrm{g} / \mathrm{kg} \mathrm{BW}$; $\mathrm{PF}=\mathrm{OVX}$ animals treated with Millettia macrophylla phenolic fraction; $\mathrm{MeOH}=\mathrm{OVX}$ animals treated with the methanol extract of $\mathrm{M}$. macrophylla. ${ }^{*} p<0.05,{ }^{* *} p<0.01,{ }^{* * *} p<0.01$ as compared with control. Lv = vaginal lumen, $\mathrm{Co}=$ stratum corneum, Gr = stratum granulosum, Ge = stratum germinativum, St: Stroma

MCF-7 cells to M. macrophylla isolates in this study; they could induce their cytotoxicity by a non-dependent ER pathway.

The E-screen assay measures the direct estrogenicity at the target cell level whereas, in animal studies there are a complexity of several systems and processes involved, including metabolism and clearance. Hence, in this study, the phenolic fraction of M. macrophylla has been tested in vivo as a whole of all the isolates.
Estrogenic effects of $M$. macrophylla phenolic fraction were assessed in vitro and in vivo. In vitro it can be seen that phenolic fraction exhibited estrogenic activity but this effect seems to be lower than the ones induced by pure compounds. This can be explained by the phenomenon of the extract dynamic and molecules interactions [56]. As for the pure compounds, the MCF-7 cells proliferation induced by phenolic fraction of $M$. macrophylla decreased with increasing concentrations. 


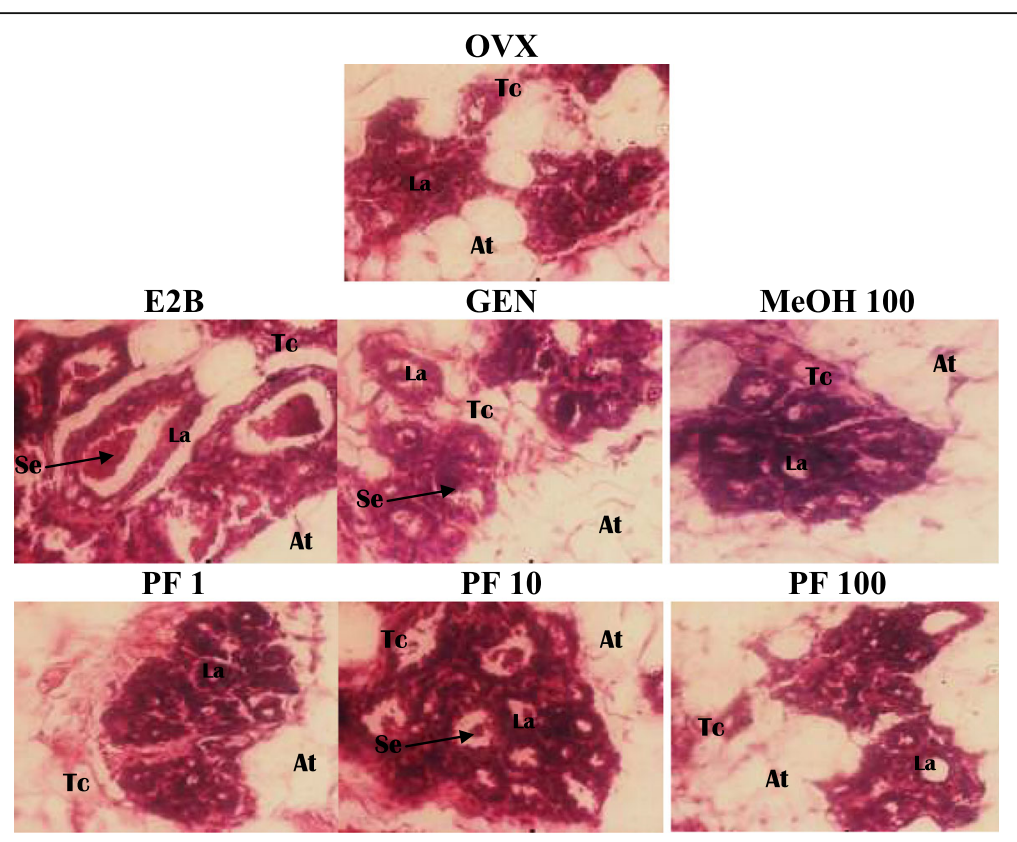

Fig. 7 Effects of a 3-day treatment with M. macrophylla extracts on mammary gland. OVX = OVX animals treated with the corn oil; E2B = OVX animals treated with estradiol benzoate $2 \mu \mathrm{g} / \mathrm{kg}$ BW; PF $=\mathrm{OVX}$ animals treated with the Millettia macrophylla phenolic fraction; $\mathrm{MeOH}=\mathrm{OVX}$ animals treated with the methanol extract of M. macrophylla. La = lumen of alveoli; Ep = aveoli epitheluim; At = adipose tissue; Se= eosinophil secretion

It has also been observed that the ability of the $M$. macrophylla phenolic fraction to transactivate ERs in reporter gene assay change with concentration. However, the M. macrophylla phenolic fraction induced a most potent transactivation of ER $\alpha$ as well as ER $\beta$ at the lower concentrations $\left(10^{-3}\right.$ and $\left.10^{-2} \mu \mathrm{g} / \mathrm{mL}\right)$ than that previously reported with methanol crude extract $\left(10^{-1}\right.$ and $10^{1} \mu \mathrm{g} / \mathrm{mL}$ ) [18]. The in vivo estrogenic activity of this fraction was assessed in an uterotrophic assay. Phenolic fraction at the dose of $10 \mathrm{mg} / \mathrm{kg}$ induced a significant increase in uterine wet weight, uterine total protein level, vaginal and uterine epithelial height as well as in mammary glands differentiation. These results confirm those previously obtained with $M$. macrophylla methanol extract on estrogen target organs [18]. However, as observed in reporter gene assay, the obtained results indicate that the phenolic fraction is more efficient than the crude methanol extract. We can hypothesized that 6 , $13,10,11,3$ as well as others potential active principles detected in $M$. macrophylla phenolic fraction are able to transactivate the ER $\alpha$ as observed in the reported gene assay and trigger proliferation of vaginal and uterine epithelial cells as it did in MCF-7 cells in vitro. Such effects have been reported to be mediated by ER $\alpha$ [57]. Cell proliferation is followed by protein synthesis increased; this can explain the observed increased of total protein level in uterus after 3 consecutive days of treatment. Authors report that this increase in protein amounts into cells is responsible for the uterine wet imbibition [58]. Conversely, the increase in the acini size of mammary gland observed in vivo with the M. macrophylla phenolic fraction, can be explained by the capacity of this fraction to induce MCF-7 cells proliferation, which are adenocarcinoma cells expressing ER $\alpha$. Further, PF induced a weak cytotoxic activity in both MCF-7 and MDA-MB-231 cells. This result can be a promising search of anti-breast cancer therapy.

The most common concern in postmenopausal women is hot flushes which are experienced by as many as $75 \%$ of menopausal women [59]. It is well documented that the effectiveness of xenobiotic in compensating the effects of estrogen deprivation can be assessed by its ability to alleviate hot flushes [60]. It appears from the analysis of core temperatures that, the average duration and frequency of hot flushes was significantly reduced in the group treated with the phenolic fraction at the dose of $10 \mathrm{mg} / \mathrm{kg}$. All these results suggest that this fraction contains secondary metabolites with estrogenic activity which can reverse the thermoregulatory dysfunction related to post-oophorectomy depletion of endogenous estrogens. Indeed, Freedman et al. [59] reported that estrogen and estrogenic substances raise the sweating threshold and expand the thermoneutral area in postmenopausal symptomatic women.

\section{Conclusion}

Millettia macrophylla has estrogenic properties, given its high amount of flavonoids as well as triterpernoids mainly, variabilin (13), aformorsin (7), pisatin (10), stigmastenone (3), flemichaparin B (11), formononetin (6), 
A

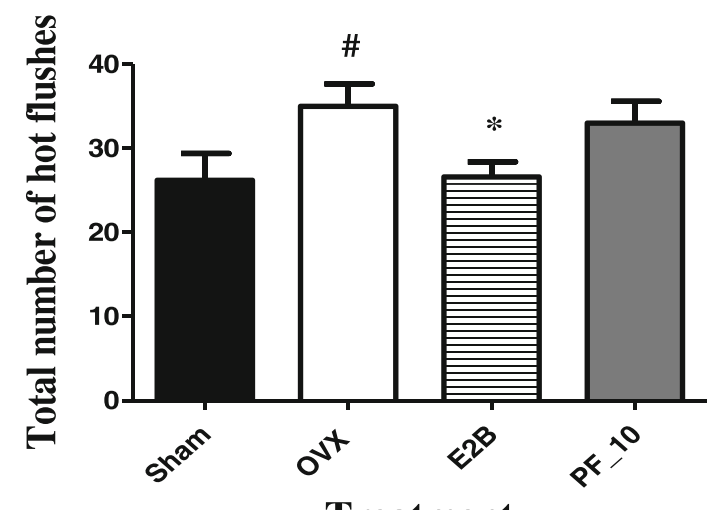

B

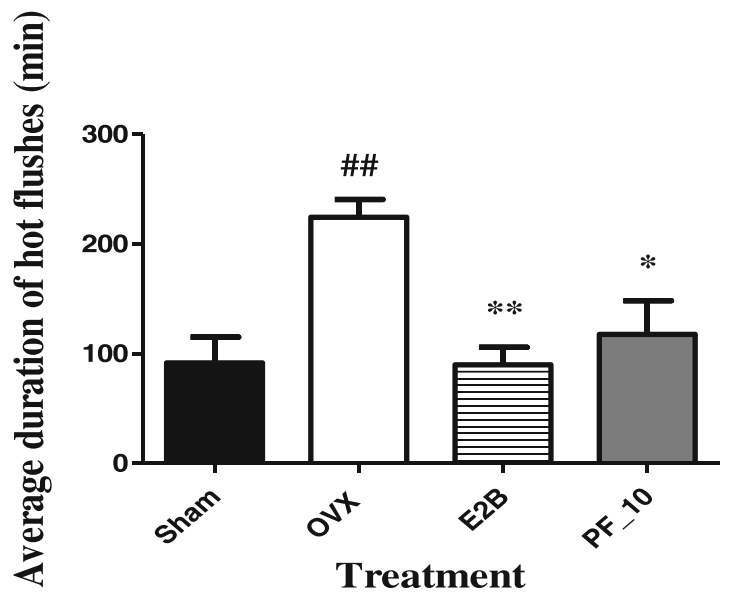

C

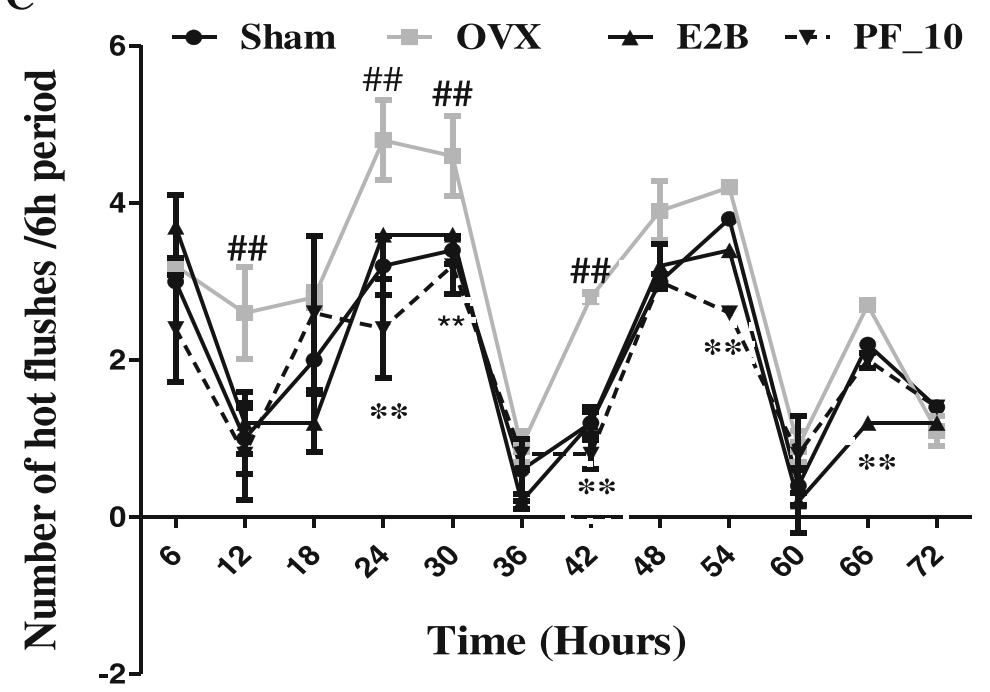

Fig. 8 Effects of a 3-day treatment with Millettia macrophylla phenolic fraction on total number (a), average duration (b) and frequency (c) of hot flushes. Sham = Sham operated rats treated with the vehicle (corn oil); OVX =OVX animals treated with the vehicle (corn oil); E2B = OVX animals treated with estradiol benzoate at $2 \mu \mathrm{g} / \mathrm{kg} \mathrm{BW;} \mathrm{PF}=\mathrm{OVX}$ animals treated with Millettia macrophylla phenolic fraction. ${ }^{*} p<0.05,{ }^{* *} p<0.01$ as compared to control. ${ }^{\#} p<0.05,{ }^{\# \#} p<0.01$ as compared to Sham 
lupeol (2), which exhibited estrogenic effects in this work. 11, 3 and 2 have been described for the first time as estrogenic in this work and together with 7, 13, 10 and 6 could be the active principles of M. macrophylla. The phenolic fraction prepared from methanol extract of $M$. macrophylla appears to be more efficient than the methanol crude extract. It could be a good candidate for the preparation of an improved traditional medicine from M. macrophylla able to alleviate some menopausal complaints such as vaginal dryness and hot flushes. However, further studies have to be developed to achieve a better understanding concerning the interactions between the ligand-receptor binding of these compounds and ERs.

\section{Additional file}

Additional file 1: Figure S1. $1 \mathrm{H} \mathrm{NMR}(600 \mathrm{MHz}, \mathrm{CD} 3 \mathrm{OD})$ spectrum of compound 6. Figure S2. ESI-MS (negative mode ionization) spectrum of compound 6. Figure S3. $1 \mathrm{H} \mathrm{NMR} \mathrm{(600} \mathrm{MHz,} \mathrm{CD3OD)} \mathrm{spectrum} \mathrm{of}$ compound 13. Figure S4. ESI-MS (positive mode ionization) spectrum of compound 13. (DOC $112 \mathrm{~kb})$

\begin{abstract}
Abbreviations
C: Compound; $\mathrm{CC}_{50}$ : Cytotoxic concentration for $50 \%$ of cells; C-hex: Cyclohexane; CNH: Cameroon national herbarium; DCM: Dichloromethane; DMEM: Dulbecco's modified eagle medium; DMSO: Dimethylsulfoxide; ER: Estrogen receptor; EtOAc: Ethylacetate; EtOH: Ethanol; F: Fraction; FBS: Fetal bovine serum; FCS: Fetal calf serum; HEPES: 4-(2-hydroxyethyl)-1-piperazine ethane sulfonic acid; HPLC: High performance liquid chromatography; MeOH: Methanol; MPLC: Medium pressure liquid chromatography; NMR: Nuclear magnetic resonance; PDA: Photodiode array; PE: Proliferative effect; PF: Phenolic fraction; RP-18: Reverse phase 18; RPE: Relative proliferative effect; RPMI: Roswell Park Memorial Institute; SRB: Sulforhodamine-B; TLC: Thin layer chromatography; UHPLC: Ultra high performance liquid chromatography; UV-vis: Ultraviolet visible
\end{abstract}

\section{Acknowledgment}

The present work has been done with the support from CNPq, Brazilian National Council for Scientific and Technological Development - Brazil and TWAS, the academy of sciences for the developing world (Grant No 190741/ 2015-5). The authors are grateful to German Academic Exchange Service (DAAD) and the Alexander von Humbolt for material support.

\section{Funding}

The authors declare that they have not received any funding for this work.

\section{Availability of data and materials}

The data and materials used in this study are available upon request from the authors.

\section{Authors' contributions}

Designed the experiments: ZS, ND, CJ, TJ, MH. Performed the phytochemical analysis ZS, TJ, MH, SLP, TDN. Performed the in vitro experiments: ZS, MNDB, CJ, WE, C-PTB. Performed the in vivo experiments: ZS, NDM, ACF, ND. Analyzed the data $(\mathrm{ZS}, \mathrm{TJ})$ and wrote the paper: $\mathrm{ZS}, \mathrm{TJ}, \mathrm{MH}$. All authors read and approved the present manuscript.

\section{Competing interests}

The authors declare that they have no competing interests.

\section{Consent for publication}

Not applicable.

\section{Ethics approval and consent to participate}

Housing of animals and all experiments were approved by the Cameroon Institutional National Ethic Committee, which adopted all procedures recommended by the European Union on the protection of animals used for scientific purposes (CEE Council 86/609; Reg. no. FWA-IRD 0001954).

\section{Author details}

'Laboratory of Physiology and Natural Products Research, Department of Live and Earth Sciences, Higher Teachers' Training College, University of Maroua, P.O. Box 55, Maroua, Cameroon. ${ }^{2}$ Department of Animal Biology and Physiology, Faculty of Sciences, University of Yaoundé I, P.O. Box 812, Yaoundé, Cameroon. ${ }^{3}$ Division of Pharmacognosy and Natural Products Chemistry, School of Pharmacy, University of Athens, Panepistimioupoli Zografou, 15771 Athens, Greece. ${ }^{4}$ Department of Pharmaceutical Sciences, Health Sciences Centre, Federal University of Santa Catarina, CEP 88040-900 Florianópolis, Santa Catarina, Brazil. ${ }^{5}$ Hudson Institute of Medical Research, Clayton, VIC 3168, Australia. ${ }^{6}$ Department of Applied Chemistry, Faculty of Sciences, University of Johannesburg, Doornfontein 2028, South Africa.

Received: 28 June 2016 Accepted: 5 October 2016

Published online: 26 October 2016

\section{References}

1. Ferlay J, Shin HR, Bray F, Forman D, Mathers C, Parkin DM. Estimates of worldwide burden of cancer in 2008: GLOBOCAN 2008. Int J Cancer. 2010;127:2893-917.

2. Sankaranarayanan R, Ferlay J. Worldwide burden of gynecological cancer: the size of the problem. Best Pract Res Clin Obstet Gynaecol. 2006;20:207-25.

3. World Health Organisation (WHO). Médecine traditionnelle, aide-mémoire $n^{\circ} 134$ Repéré à http://www.who.int/mediacentre/factsheets/fs134/fr/index.html. 2012.

4. Baliga MS, Dsouza JJ. Amla (Emblica officinalis Gaertn), a wonder berry in the treatment and prevention of cancer. Eur J Cancer Prev. 2011;20:225-39.

5. Fregene A, Newman LA. Breast cancer in sub-Saharan Africa: how does it relate to breast cancer in African-American women? Cancer. 2005;103:1540-50.

6. Sinha D, Biswas J, Sung B, Aggarwal BB, Bishayee A. Chemopreventive and chemotherapeutic potential of curcumin in breast cancer. Curr Drug Targets. 2012;13:1799-819.

7. Parikh NR, Mandal A, Bhatia D, Siveen KS, Sethi G, Bishayee A. Oleanane triterpenoids in the prevention and therapy of breast cancer: current evidence and future perspectives. Phytochem Rev. 2014;13:793-810.

8. Magne Nde CB, Zingue S, Winter E, Creczynski-Pasa TB, Michel T, Fernandez X, Njamen D, Clyne C. Flavonoids, Breast Cancer Chemopreventive and/or Chemotherapeutic Agents. Curr Med Chem. 2015;22:3434-46.

9. Sinha D, Sarkar N, Biswas J, Bishayee A. Resveratrol for breast cancer prevention and therapy: Preclinical evidence and molecular mechanisms. Semin Cancer Biol. 2016;doi:10.1016/j.semcancer.2015.11.001.

10. Ososki AL, Kennelly EJ. Phyoestrogens: a review of present state of research. Phytother Res. 2003;17:845-69.

11. Hughes CL. Phytochemical mimicry of reproductive hormones and modulation of herbivore fertility by phytoestrogens. Environ Health Persp. 1988;78:171-5.

12. Miksicek RJ. Commonly Occurring Plant Flavonoids Have Estrogenic Activity. Mol Pharmacol. 1993;44:37-43.

13. Adlercreutz H, Mazur W, Stumpf K, Kilkkinen A, Pietinen P, Hulten K, Hallmans G. Phytoestrogens and breast cancer risks. Biofactors. 2000;12:89.

14. Banzouzi JT, Prost A, Rajemiarimirabo M, Ongoka P. Traditional uses of African Millettia species (Fabaceae). Inter J Bot. 2008:4:406-20.

15. Lawal IO, Uzokwe NE, Igboanugo ABI, Adio AF, Awosan EA, Nwogwugwu JO. Ethnomedicinal information on collation and identification of some medicinal plants in Research Institutes of South-west Nigeria. Afr J Pharm Pharmacol. 2010;4:001-7.

16. Ito C, Itoigawa M, Kojima N, Tokuda H, Hirata T, Nishino H, Furukawa H. Chemical Constituents of Millettia taiwaniana: Structure Elucidation of Five New Isoflavonoids and Their Cancer Chemopreventive Activity. J Nat Prod. 2004;67:1125-30.

17. Rayanil K-O, Bunchornmaspan P, Tuntiwachwuttikul P. A new phenolic compound with anticancer activity from the wood of Millettia leucantha. Arch Pharm Res. 2011;34:881-6.

18. Zingue S, Njamen D, Tchoumtchoua J, Halabalaki M, Simpson E, Clyne C, Magne Nde CB. Effects of Millettia macrophylla (Fabaceae) extracts on estrogen target organs of female Wistar rat. J Pharm Sci. 2013;123:120-31. 
19. Zingue S, Njamen D, Mvondo MA, Magne Nde CB. Preventive effects of the methanol soluble fraction of Millettia macrophylla Benth (Fabaceae) on an osteoporosis-like model of ovariectomized Wistar rats. J Compl Integr Med. 2014;11:83-92

20. Zingue S, Magne Nde CB, Clyne C, Njamen D. Elucidation of underlying mechanisms by which Millettia macrophylla Benth induces its estrogenic activity. ISRN. 2014;763781(2014b):8.

21. Clarke R, Liu MC, Bouker KB, Gu Z, Lee RY, Zhu Y, Skarr TC, Wang Y, HilakivClarke LA. Antiestrogen resistance in breast cancer and the role of estrogen receptor signaling. Oncogene. 2003;22:7316-39.

22. Ahmed SA, Gogal Jr MR, Walsh EJ. A new rapid and simple non-radioactive assay to monitor and determine the proliferation of lymphocytes: an alternative to [3H]thymidine incorporation assay. J Immunol Methods. 1994;170:211-24.

23. Resende FA, de Oliveira APS, de Camargo MS, Vilegas W, Varanda EA. Evaluation of Estrogenic Potential of Flavonoids Using a Recombinant Yeast Strain and MCF7/BUS Cell Proliferation Assay. PLoS One. 2013:8:74881.

24. Soto AM, Lin TM, Justicia H, Silvia RM, Sonnenschein C. An "in culture" bioassay to assess the estrogenicity of xenobiotics. In: Colborn T, Clement C, editors. Chemically induced alterations in sexual development: The wildlife/human connection. Princeton: Princeton Scientific Publishing; 1992. p. 295-309.

25. Schiliro' T, Gorrasi I, Longo A, Coluccia S, Gilli G. Endocrine disrupting activity in fruits and vegetables evaluated with the E-screen assay in relation to pesticide residues. J Steroid Biochem Mol Biol. 2011;127:139-46.

26. Lane NE, Yao W, Kinney JH, Modin G, Balooch M, Wronski TJ. Both hPTH (134) and bFGF increase trabecular bone mass in osteopenic rats but they have different effects on trabecular bone architecture. J Bone Miner Res. 2003;18:2105-15

27. Zingue S, Michel T, Tchatchou J, Magne Nde CB, Winter E, Monchot A Awounfack CF, Djiogue S, Clyne C, Fernandez X, Creczynski-Pasa TB, Njamen D. Estrogenic effects of Ficus umbellata Vahl. (Moraceae) extracts and their ability to alleviate some menopausal symptoms induced by ovariectomy in Wistar rats. J Ethnopharmacol. 2016;179:332-44.

28. Gonal AG, Bardwill GS, David MM. Determination of serum proteins by the means of biuret reactions. J Biol Chem. 1949;177:751-66.

29. Imam S, Azhar I, Hasan MM, Ali MS, Ahmed SW. Two triterpenes lupanone and lupeol isolated and identified from Tamarindus indica linn. Pak J Pharm Sci. 2007;20:125-7

30. Jain PS, Bari SB. Isolation of lupeol, stigmasterol and campesterol from petroleum ether extract of woody stem of Wrightia tinctoria. Asian J Plant Sci. 2010;9:163-7.

31. Radulović NS, Đorđević ND. Steroids from poison hemlock (Conium maculatum L.): a GC-MS analysis. J Serb Chem Soc. 2011;76:1471-83.

32. Pavićević ID, Jovanović VB, Takić MM, Penezić AZ, Aćimović JM. Fatty acids binding to human serum albumin: Changes of reactivity and glycation level of Cysteine-34 free thiol group with methylglyoxal. Chem Biol Interact. 2014;22:442-50

33. Feng S, Hao J, Xu Z, Chen T, Qiu SX. Polyprenylated isoflavanone and isoflavonoids from Ormosia henryi and their cytotoxicity and anti-oxidation activity. Fitoterapia. 2012:83:161-5.

34. Tchoumtchoua J, Njamen D, Mbanya JC, Skaltsounis AL, Halabalaki M. Structure-oriented UHPLC-LTQ Orbitrap-based approach as a dereplication strategy for the identification of isoflavonoids from Amphimas pterocarpoides crude extract. J Mass Spectrom. 2013;48:561-75.

35. Li F, Awale S, Tezuka Y, Kadota S. Cytotoxic constituents from Brazilian red propolis and their structure-activity relationship. Bioorg Med Chem. 2008;16:5434-40

36. Li W, Koike K, Asada Y, Hirotani M, Rui H, Yoshikawa T, Nikaido T. Flavonoids from Glycyrrhiza pallidiflora hairy root cultures. Phytochemistry. 2002;60:351-5.

37. Perrin DR, Bottomley W. Pisatin: an antifungal substance from Pisum sativum L. Nature. 1961;191:76-7.

38. Adityachaudhury N, Gupta PK. A new pterocarpan and coumestan in the roots of Flemingia chappar. Phytochemistry. 1973;12:425-8.

39. Lee JH, Lee BW, Kim JH, Jeong T-S, Kim MJ, Lee WS, Park HK. LDLAntioxidant Pterocarpans from Roots of Glycine max (L.) Merr. J Agric Food Chem. 2006;54:2057-63.

40. Sato S, Takeo J, Aoyama C, Kawahara H. Na + -Glucose cotransporter (SGLT) inhibitory flavonoids from the roots of Sophora flavescens. Bioorg Med Chem. 2007:15:3445-9.

41. Korner W, Hanf V, Schuller W, Kempter C, Metzger J, Hagenmaier H. Development of a sensitive E-screen assay for quantitative analysis of estrogenic activity in municipal sewage plant effluents. Sci Total Environ. 1999:225:33-48.

42. Choi SY, Ha TY, Ahn JY, Kim SR, Kang KS, Hwang IK, Kim S. Estrogenic activities of isoflavones and flavones and their structure-activity relationships. Planta Med. 2008;74:25-32.

43. Zand RS, Jenkins DJ, Diamandis EP. Steroid hormone activity of flavonoids and related compounds. Breast Cancer Res Treat. 2000;62:35-49.

44. Khan K, Sharan K, Swarnkar G, Chakravarti B, Mittal M, Barbhuyan TK, China SP, Khan MP, Nagar GK, Yadav D, Dixit P, Maurya R, Chattopadhyay N. Positive skeletal effects of cladrin, a naturally occurring dimethoxydaidzein, in osteopenic rats that were maintained after treatment discontinuation. Osteoporos Int. 2013;24:1455-70.

45. Ji Z-N, Zhaoa WY, Liaob GR, Choic RC, Loc CK, Dong TTX, Tsim KWK. In vitro estrogenic activity of formononetin by two bioassay systems. Gynecol Endocrinol. 2006:22:578-84.

46. Hegazy M-EF, El-Mohamed AHH, El-Halawany AM, Djemgou PC, Shahat AA, Paré PW. Estrogenic Activity of Chemical Constituents from Tephrosia candida. J Nat Prod. 2011;74:937-42.

47. Boue SM, Tilghman SL, Elliott S, Zimmerman MC, Williams KY, PaytonStewart F, Miraflor AP, Howell MH, Shih BY, Carter-Wientjes CH, Segar C, Beckman BS, Wiese TE, Cleveland TE, McLachlan JA, Burow ME. Identification of the Potent Phytoestrogen Glycinol in Elicited Soybean (Glycine max). Endocrinology. 2009;150:2446-53.

48. Kovalchuk SN, Kozhemyako VB, Atopkina LN, Silchenko AS, Avilov SA, Kalinin VI, Rasskazov VA, Aminin DL. Estrogenic activity of triterpene glycosides in yeast two-hybrid assay. J Steroid Biochem Mol Biol. 2006;101:226-31.

49. Chan RK, Chen WF, Dong A, Guo D, Wong MS. Estrogen-like activity of ginsenoside Rg1 derived from Panaxnotoginseng. J Clin Endocrinol Metab. 2002;87:3691-5.

50. Zin SRM, Omar SZ, Khan NLA, Musameh NI, Das S, Kassim NM. Effects of the phytoestrogen genistein on the development of the reproductive system of Sprague Dawley rats. Clinics. 2013;68:253-62.

51. Mellanen P, Petanen T, Lehtimaki J, Makela S, Bylund G, Holmbom B, Mannila E, Oikar A, Santti R. Wood-Derived Estrogens: Studies in vitro with Breast Cancer Cell Lines and in vivo in Trout. Toxicol Appl Pharmacol. 1996;136:381-8.

52. Omeje EO, Khan MP, Osadebe PO, Tewari D, Khan MF, Dev K, Maurya R, Chattopadhyay N. Analysis of constituents of the eastern Nigeria mistletoe, Loranthus micranthuslinn revealed presence of new classes of osteogenic compounds. J Ethnopharmacol. 2014;151:643-51.

53. Chaudhary S, Chandrashekar SK, Pai KSR, Setty MM, Devkar RA, Reddy ND, Shoja MH. Evaluation of antioxidant and anticancer activity of extract and fractions of Nardostachys jatamansi DC in breast carcinoma. BMC Complemen Altern Med. 2015;15:50-63.

54. Pitchai $D$, Roy $A$, Ignatius $C$. In vitro evaluation of anticancer potentials of lupeol isolated from Elephantopus scaber L. on MCF-7 cell line. J Adv Pharm Technol Res. 2014:5:179-84.

55. Rice S, Whitehead SA. Phytoestrogens and breast cancer promoters or protectors? Endocr Relat Cancer. 2006;13:995-1015.

56. Fugh-Berman A. Herb-drug interactions. Lancet. 2000;355:134-8.

57. Hewitt SC, Korach KS. Estrogen receptor knockout mice: roles for estrogen receptors alpha and beta in reproductive tissues. Reproduction. 2003;125:143-9.

58. Hewitt SC, Deroo BJ, Hansen K, Collins J, Grissom S, Afshari CA, Korach KS. Estrogen receptor-dependent genomic responses in the uterus mirror the biphasic physiological response to estrogen. J Mol Endocrinol. 2003;17:2070-83.

59. Freeman EW, Sammel MD, Sanders RJ. Risk of long-term hot flashes after natural menopause: evidence from the Penn Ovarian Aging Study cohort. Menopause. 2014:21:924-32.

60. Girbig D, Keller K, Prelle K, Patchev V, Vonk R, Bernd-Wolfgang I. A dynamic model of circadian rhythms in rodent tail skin temperature for comparison of drug effects. J Circadian Rhythms. 2012;10:2-11. 